\title{
Pessoas coletivas e os programas de compliance: a problemática da prova compartilhada com o processo penal de pretensão democrática
}

\author{
Legal persons and compliance programs: the problem of proof shared \\ with the criminal process of democratic pretension
}

\author{
Francisco de Assis de França Júnior ${ }^{1}$ \\ Universidade de Coimbra - Portugal \\ fafjunior2016@gmail.com \\ http://lattes.cnpq.br/2739102277898461 \\ Dittp://orcid.org/0000-0002-6958-920X
}

\begin{abstract}
Resumo: O presente artigo tem como objetivo principal analisar criticamente a produção e o possível compartilhamento de provas originárias de programas de compliance com o processo penal que se pretende democrático. Nesse contexto, a partir de revisão bibliográfica, procuramos demonstrar potenciais implicações de direitos de defesa e alguns dos aspectos da tendência de privatização de deveres tradicionalmente estatais. Por fim, concluímos pela utilização válida de provas provenientes de investigadores particulares desde que sejam respeitados os mesmos limites atualmente vigentes para o regular funcionamento do processo penal em ambiente democrático.
\end{abstract}

Palavras-chave: Programas de compliance; Prova compartilhada; Processo penal; Democracia.

ABSTRACT: The main objective of this paper is to critically analyze the production and possible sharing of evidence originating from compliance programs with the criminal process that is intended to be democratic. In this context, from a bibliographical review, we try to demonstrate potential implications of defense

1 Doutorando e Mestre pela Faculdade de Direito da Universidade de Coimbra; Pesquisador visitante no Max-Planck-Institut für ausländisches und internationales Strafrecht; Coordenador adjunto do Instituto Brasileiro de Ciências Criminais - IBCCRIM no Estado de Alagoas; Professor no Centro Universitário CESMAC (Maceió/AL); advogado. 
rights and some aspects of the tendency of privatization of traditionally state duties. Finally, we conclude that valid evidence is being used by private investigators as long as the same limits currently in force for the regular functioning of criminal proceedings in a democratic environment are respected.

KeYwords: Compliance programs; Proof shared; Criminal proceedings; Democracy.

SUMÁRIO: 1. Introdução; 2. Pessoas coletivas e os programas de compliance: uma inevitável aproximação; 3. A produção de prova no âmbito dos programas de compliance e a potencial implicação de direitos e garantias fundamentais: é possível uma privatização de um dever tradicionalmente estatal?; 4. O compartilhamento (e o empréstimo) da prova com o processo penal de pretensão democrática; 5. Considerações finais; Referências.

\section{INTRODUÇÃO}

A responsabilização das pessoas coletivas é um daqueles temas cuja repercussão não há de se restringir ao âmbito da dogmática jurídico-penal. Muito pelo contrário. Sua dimensão, além de questões sociais e políticas, abarca ainda poderosíssimos interesses financeiros e econômicos. Daí que uma atuação direta do direito penal sobre elas tem merecido especial atenção de legisladores, doutrinadores, juízes e, como é óbvio, do próprio empresariado nas mais variadas circunstâncias. Não obstante essa entusiasmada mobilização, percebe-se claramente que nem todos os aspectos relevantes desse debate têm sido observados com a mesma intensidade.

No embalo do desenvolvimento econômico, a institucionalização da responsabilidade das pessoas coletivas na esfera penal acabou por desencadear uma espécie de relativização dos paradigmas iluministas até então vigentes. ${ }^{2}$ Ou seja, os mecanismos usuais de alegadas prevenção e

2 ANTUNES, Maria João. A responsabilidade criminal das pessoas colectivas entre o direito penal tradicional e o novo direito penal. Lusíada: Revista de 
retribuição haviam sido moldados essencialmente para pessoas de carne e osso, não para aquele tipo de abstração. Não foi à toa que vimos popularizada a máxima societas delinquere non potest. ${ }^{3}$ Partia-se, portanto, do pressuposto de que tais pessoas não podiam ostentar capacidade de ação ou de culpa, tampouco podiam sofrer uma pena de prisão, características que só poderiam ser direcionadas, como parecia evidente, às pessoas físicas. ${ }^{4}$

No entanto, com autoridades engajadas politicamente, a responsabilização penal das pessoas coletivas passou a ser consagrada nos ordenamentos espalhados pelo mundo, ${ }^{5}$ o que ocorreu mais entusiasmadamente em países tributários do common law, ${ }^{6}$ como é, na generalidade, o caso dos Estados Unidos. ${ }^{7}$ Registre-se, en passant, que é esse direito

direito e cultura, Porto, n. 1-2, 2003. p. 359.

3 Para uma análise aprofundada sobre esse contexto, por todos, recomenda-se: FIGUEIREDO DIAS, Jorge. Para uma dogmática do direito penal secundário. In: IDPEE - Direito penal económico e europeu: textos doutrinários. V. I. Coimbra: Coimbra, 1998.

4 "O direito penal só podia ser aplicado a seres humanos, vivos, capazes de discernimento e cuja inteligência e vontade não tivessem sofrido nenhum dano". (LAINGUI, André. Sur quelques sujets non-humains des anciens droits pénaux. ROBERT, Jacques-Henri; TZITIS, Stamatios. La personne juridique dans la philosophie du droit penal. Paris: Éditions Panthéon Assar, 2001. p. 13) (tradução livre).

5 Apenas para que se tenha uma ligeira ideia do que essa disseminação representa atualmente, na Europa, por exemplo, para que não nos alonguemos, tem-se: Bélgica, Dinamarca, Estônia, Finlândia, França, Holanda, Irlanda, Islândia, Letônia, Lituânia, Luxemburgo, Noruega, Polônia, Portugal, Espanha, Reino Unido, Suécia e Suíça. BEVIÁ, Jordi Gimeno. Compliance y proceso penal. El proceso penal de las personas jurídicas - adaptada a las reformas del CP LECRIM, circular FGE 1/2016 y jurisprudencia del TS. Navarra: Aranzadi, 2016. p.30. Além disso, atente-se para o fato de que o termo "pessoa coletiva", que é o adotado em Portugal, possui relativas variações a depender do país. No Brasil, por exemplo, a terminologia convencionada, pelo próprio legislador, é a de "pessoa jurídica".

6 FARIA COSTA, José de; COSTA ANDRADE, Manuel da. Sobre a concepção e os princípios do direito penal económico. In: IDPEE - Direito penal económico e europeu: textos doutrinários. V. I. Coimbra: Coimbra, 1998. p. 347 ss.

7 É paradigmática a decisão de 1909 no caso New York Central \& Hudson River Railroad $v$ s United States. BEVIÁ, Jordi Gimeno. Compliance y proceso penal. El proceso penal de las personas jurídicas - adaptada a las reformas del CP LECRIM, circular FGE 1/2016 y jurisprudencia del TS. Navarra: Aranzadi, 2016. p. 30. 
americano que, mesmo nos países do civil law, influencia a opção por esse tipo de responsabilização, sobretudo na Europa. ${ }^{8}$ Com uma obstinação em tentar evitar/reparar prejuízos financeiros e econômicos, formou-se um caudal de argumentos de natureza prática que desembocou no que atualmente conhecemos por direito penal econômico.

É com o aumento desse interesse estatal sobre as pessoas coletivas na dinâmica social moderna - e, consequentemente, com a criação de mecanismos de controle e de eventual responsabilização - que se fertiliza o terreno para o aparecimento dos programas de compliance, ${ }^{9}$ o objeto do interesse central da presente pesquisa. Temerosa por conta da atuação do direito penal nas liberdades fundamentais, parte significativa do empresariado tem se antecipado com programas direcionados aos riscos que as atividades empresariais comportam. A partir daí, um complexo sistema de boa governança tem sido moldado com o intuito de dificultar, ao máximo, desvios no exercício de funções vinculadas à empresa.

Assim, verificamos ultimamente empresas que se obrigam a manusear, mais do que meros mecanismos de prevenção, autônomos sistemas de investigação e de responsabilização que possuem contornos diferentes daqueles que normalmente encontramos num processo penal de pretensão democrática. Amparados pelas próprias regras, aqueles que investigam nesse tipo de ambiente, cuja natureza é essencialmente privada, não raro, buscam proteger a imagem da empresa. Não é, por exemplo, o que normalmente se observa da atuação do Ministério Público, em que, quando se investiga, o direcionamento dá-se quase sempre no sentido de cobrar a condenação dos envolvidos.

8 MARTÍN, Adán Nieto. ¿Americanización o europeización del Derecho Penal económico? Revista Penal, España, n. 19, p. 120-136, 2007. E ainda: MARTÍN, Adán Nieto. La corrupción en el comercio internacional (o de cómo la americanización del derecho penal puede tener de vez en cuando algún efecto positivo). Revista Penal, España, n. 12, p. 3-26, 2003.

9 Anabela Miranda Rodrigues, em texto publicado recentemente, entre outras preocupações, recorda-nos “como o 'capitalismo regulatório', através de um de seus elementos essenciais - os programas de cumprimento (compliance) -, procurou edificar uma estratégia de controlo da atividade económica ilícita”. RODRIGUES, Anabela Miranda. Direito penal económico - é legítimo? É necessário? Revista Brasileira de Ciências Criminais, São Paulo, ano 25, n. 127, 2017. p. 16. 
Desse modo, o que apontamos como deficitário nesse tipo de debate está relacionado com a dinâmica de produção, compartilhamento e empréstimo de provas. ${ }^{10}$ Dada a polissemia ínsita ao termo prova, cumpre-nos, desde logo, destacar que, em bom rigor, sabemos que a prova emprestada e a prova compartilhada possuem realidades tecnicamente diferentes. ${ }^{11}$ Em apertada síntese, quando fazemos circular provas sem que tenham passado pelo devido contraditório, temos uma espécie de compartilhamento, e não de empréstimo. Empresta-se uma prova apenas quando ela originalmente passou por um processo marcado pelo contraditório. Mas disso, logo se perceberá, não nos ocuparemos de maneira pormenorizada. ${ }^{12}$

Nesse passo, questão nevrálgica é sabermos (se e) como as provas produzidas nesses programas de compliance poderiam vir a ser aproveitadas validamente no âmbito de um processo penal que se pretende democrático, ou seja, em um ambiente que, em termos de investigação, preza pelos paradigmas (discursivos) que norteiam uma substancial democracia (ampla defesa, contraditório, presunção de inocência, entre outros importantes valores com os quais vamos dialogar a seguir) muito

10 "De uma forma intencionalmente clara, o CPP [Código de Processo Penal] distingue os meios de obtenção da prova dos meios de prova, constituindo o objeto da prova todos os factos juridicamente relevantes para a existência ou inexistência do crime, a punibilidade ou não punibilidade do arguido e a determinação da pena ou da medida de segurança aplicáveis (artigo $124^{\circ}$ do CPP). É através dos meios de obtenção da prova que são obtidos os meios de prova a partir dos quais se forma a convicção das autoridades judiciárias". ANTUNES, Maria João. Direito processual penal. Coimbra: Almedina, 2016. p. 110. Por uma questão de praticidade, no desenvolvimento da presente pesquisa, utilizamos apenas a expressão "prova", tal como é utilizada na legislação brasileira (artigo 155 ss. do CPP), ao invés de "meios de prova", como prescrito na referida legislação portuguesa. Vale, no entanto, destacar, que, no Brasil, tal distinção é a adotada pelo projeto de novo código de processo penal (Projeto de Lei do Senado n. 156/2009).

11 Devo o alerta à Senhora Professora Doutora Inês Fernandes Godinho, que, em encontro sob a coordenação da Senhora Professora Doutora Maria José Capelo, em 4/5/2018, na Casa da Jurisprudência, em Coimbra, abordou o assunto.

12 Embora tenhamos optado pelo alerta da diferenciação, o que se percebe é que não há recorrência na doutrina sobre tal aspecto. Veja-se, como representativo dessa indiferença: BADARÓ, Gustavo Henrique Righi Ivahy. Processo penal. 4. ed. São Paulo: RT, 2016. p. 395 ss. 
especialmente na prática de seus agentes. Será preciso, em certa medida, explicitar, analisar e até mesmo propor certos pontos de contato entre os mecanismos pesquisados.

É, portanto, a partir de uma pontual revisão bibliográfica, que avaliaremos sucintamente se não estaríamos diante de uma espécie indevida de privatização de investigação tradicionalmente estatal. Nosso objetivo principal é o de procurar estimular reflexões críticas sobre eventuais violações aos direitos fundamentais, sempre a partir dos procedimentos enfocados.

\section{Pessoas coletivas e os programas de compliance: uma INEVITÁVEL APROXIMAÇÃO}

É inegável que nas últimas décadas a economia tem assumido uma preponderância jamais vista na dinâmica social. Se há uma estrutura que conseguiu a proeza de se conectar uniforme e eficientemente com praticamente todos os países do globo, é a econômica. Para António Pinto Monteiro $^{13}$, a intensidade desse fenômeno na modernidade foi o que nos proporcionou uma verdadeira "aceleração histórica", que correspondeu, como é evidente, a “uma acentuada mudança no fenómeno jurídico”. É a partir desse contexto que René Savatier ${ }^{14}$ aponta para uma indigesta "inflação legislativa", com o que também nos foram apresentados "efeitos perniciosos ao nível da cognoscibilidade das regras jurídicas". ${ }^{15}$

Esse processo evolutivo, proporcionado pelo dinamismo com o qual o tecido social passou a se movimentar, sobretudo a partir do século

13 PINTO MONTEIRO. António. Cláusulas limitativas e de exclusão de responsabilidade civil. Dissertação para exame de pós-graduação em Ciências Jurídico-Civis na Faculdade de Direito da Universidade de Coimbra. Coimbra: Coimbra, 1985. p. 14.

14 SAVATIER, René. L'inflation législative et l'indigestion du corps social. Paris: Dalloz, 1977. Recomenda-se ainda: SAVATIER, René. Les Métamorphoses économiques et sociales du Droit Civil d'Aujourd'hui. $3^{\mathrm{a}}$ ed. Paris: Dalloz, 1964.

15 PINTO MONTEIRO. António. Cláusulas limitativas e de exclusão de responsabilidade civil. Dissertação para exame de pós-graduação em Ciências Jurídico-Civis na Faculdade de Direito da Universidade de Coimbra. Coimbra: Coimbra, 1985. p. 14. 
XX, levou o direito a se estruturar como um "sistema aberto", ou seja, "não logicamente fechado e concluso e de mero desenvolvimento progressivo (implícito ou analítico), mas materialmente aberto a novos conteúdos, a novas aquisições e a possíveis mutações histórico-normativas [...]"16. Temos, na generalidade, um sistema que se adaptou ao diálogo com as necessidades mais práticas das pessoas, dotado, portanto, de um instrumental que "não poderá alhear-se da realidade concreta que pretende conformar"17. O que não significa dizer que não existam limites.

Desse modo, o crescente interesse do direito - e em especial do direito penal - pelas pessoas coletivas não surgiu do nada, senão como resultado das circunstâncias que, embora delineadas a traços largos, deixamos antever. A deflagração desse movimento de normatização da dinâmica social não demoraria até chegar à pessoa coletiva, assim como também não tardaria até chegar ao seu interior. ${ }^{18}$ Tanto é assim que já convivemos com uma indigesta quantidade de programas de compliance. Para Adán Nieto Martín ${ }^{19}$, tais normas internas acabam por se assemelhar a uma espécie de grande rio, onde desembocam numerosos afluentes de procedências diversas.

Pese essa proliferação de normas de autorregulação $-{ }^{20}$ que podem vir a variar de uma empresa para outra -, se partirmos da ideia de que a

16 CASTANHEIRA NEVES, António. Lições de introdução ao estudo do direito. Coimbra: Coimbra, 1968-69, 329 ss.

17 PINTO MONTEIRO. António. Cláusulas limitativas e de exclusão de responsabilidade civil. Dissertação para exame de pós-graduação em Ciências Jurídico-Civis na Faculdade de Direito da Universidade de Coimbra. Coimbra: Coimbra, 1985. p. 15.

18 “a empresa foi 'descoberta' pelo direito penal e pela criminologia como um centro susceptível de gerar ou de favorecer a prática de factos penalmente ilícitos, porque de repercussão desvaliosa no tecido económico-social”. FARIA COSTA, José de. A responsabilidade jurídico-penal da empresa e dos seus órgãos (ou uma reflexão sobre a alteridade nas pessoas colectivas à luz do direito penal). Revista Portuguesa de Ciência Criminal, Lisboa, ano 2, n. 4, out.-dez., 1992. p. 543.

19 MARTÍN, Adán Nieto. Problemas fundamentales del cumplimiento normativo en el derecho penal. KUHLEN, Lothar; MONTIEL, Juan Pablo; URBINA GIMENO, Íñigo Ortiz de. Compliance y teoría del derecho penal. Madrid: Marcial Pons, 2013. p. 23.

20 CRAWFORD, Adam; HUCKLESBY, Anthea (ed.). Legitimacy and compliance in criminal justice. New York: Routledge, 2013. p. 4. 
utilização do direito penal em ambiente pretensamente democrático deve mesmo se manter nos limites de um "mínimo ético"21, não deve ser de todo ruim que tenhamos tantas opções à mão. O que há de incomodar, no entanto, é a falta de critérios relativamente seguros que nos auxiliem, quando necessário, na acoplagem ${ }^{22}$ desse sistema de natureza privada com o sistema penal. Afinal, não percamos de vista que, como veremos adiante, mesmo numa investigação da própria empresa, são possíveis reflexos negativos em direitos e garantias historicamente consagradas no ordenamento posto.

Uma aproximação, ao que nos parece, merece (e deve) ser conduzida pelo processo penal. Com a disponibilização de mecanismos que nos permitam proteger eficientemente o que se idealizou como bem jurídico e, por consequência, a respeitar os valores consagrados tradicionalmente em ambientes democráticos. Mas essa não é uma questão com a qual nos ocuparemos agora. Sobre ela, aliás, discorreremos mais detidamente no capítulo que segue. A questão que aqui nos interessa é a de saber ao certo em que consistem os programas de compliance. Para já, se nos é permitido utilizar a metáfora de Adán Nieto Martín ${ }^{23}$, importa conhecermos quais os principais "afluentes" desse grande rio disposto à nossa frente.

Antes, porém, destaque-se que as Nações Unidas divulgaram uma série de princípios para um pacto mundial com vistas à promoção de uma "cidadania corporativa" 24 . Lançado em 26 de julho de 2000, o documento, intitulado Global Compact ${ }^{25}$, pretendia incentivar empresas

21 FARIA COSTA, José de. Noções fundamentais de Direito Penal - fragmenta iuris poenalis. $4^{\mathrm{a}}$ ed. Coimbra: Coimbra, 2015. p. 174 ss.

22 Dito no sentido luhmanniano, tal como se pode aprofundar em: LUHMANN, Niklas. El derecho de la sociedad. México: Universidad Iberoamericana, 2002; Recomenda-se ainda: LUHMANN, Niklas. Sociologia do Direito. v. I e II. Rio de Janeiro: Edições Tempo Brasileiro, 1983.

MARTÍN, Adán Nieto. Problemas fundamentales del cumplimiento normativo en el derecho penal. KUHLEN, Lothar; MONTIEL, Juan Pablo; URBINA GIMENO, Íñigo Ortiz de. Compliance y teoría del derecho penal. Madrid: Marcial Pons, 2013. p. 23.

24 BEVIÁ, Jordi Gimeno. Compliance y proceso penal. El proceso penal de las personas jurídicas - adaptada a las reformas del CP LECRIM, circular FGE 1/2016 y jurisprudencia del TS. Navarra: Aranzadi, 2016. p. 30.

25 Disponível em: <https://www.unglobalcompact.org/what-is-gc/mission>. Acesso em 22 mar. 2018. 
a: 1) Fazer negócios de forma responsável, alinhando suas estratégias e operações com dez princípios sobre direitos humanos, trabalho, meio ambiente e combate à corrupção; e 2) Tomar ações estratégicas para avançar objetivos sociais mais amplos, tais como os Objetivos de Desenvolvimento Sustentável das Nações Unidas, com ênfase na colaboração e inovação. Mas só em 2004 instituiu-se como princípio (10) que "as empresas devem trabalhar contra a corrupção em todas as suas formas, incluindo a extorsão e o suborno". ${ }^{26}$

Também os órgãos vinculados à União Europeia se ocuparam, por vezes, do tema do comportamento das pessoas coletivas. É possível constatarmos tal interesse, por exemplo, na recomendação 18/88, de 20 de outubro, do Comité de Ministros dos Estados-Membros, nas decisõesquadro do Conselho (2004/757, de 25 de outubro; 2005/667, de 12 de julho; 2005/222, de 24 de janeiro; entre outras) ${ }^{27}$ e nas diretivas (em especial, para que não nos alonguemos: 2013/34/UE, de 26 de junho; 2014/95/UE, de 22 de outubro, entre outras). O que se percebe é que as empresas têm sido pressionadas a adequarem suas estruturas a modelos de governança que privilegiem certa transparência e que possuam mecanismos eficientes de prevenção, investigação e responsabilização no caso de eventuais desvios.

Dada a flagrante diversidade de empresas espalhadas pelo mundo, e as culturas diversas com as quais elas se relacionam, a preocupação central de tais órgãos (regionais e internacionais) tem sido com o estabelecimento de alguma uniformização no trato das questões que são entendidas como potencialmente prejudiciais ao regular funcionamento da dinâmica social. Com a globalização, problemas locais e regionais estão cada vez mais conectados uns com os outros. Portanto, parece-nos compreensível que se busque instituir modelos de uma política de responsabilidade

26 O enfrentamento da corrupção, aliás, tem sido apontado como um dos principais responsáveis pelo crescimento dos debates sobre os programas de compliance. Para aprofundar esse aspecto, recomenda-se: MANACORDA, Stefano; CENTONZE, Francesco; FORTI, Gabrio. (ed.) Preventing Corporate Corruption - the anti-bribery compliance model. New York: Springer, 2014.

27 BEVIÁ, Jordi Gimeno. Compliance y proceso penal. El proceso penal de las personas jurídicas - adaptada a las reformas del CP LECRIM, circular FGE 1/2016 y jurisprudencia del TS. Navarra: Aranzadi, 2016. p. 30. 
supranacional amparados por algum lastro científico e que favoreçam a aproximação e a colaboração entre os envolvidos.

Registre-se ainda que um estudo sobre uma eventual uniformização dos programas de compliance deve implicar também questões relacionadas à sua legitimidade. No entanto, não será propriamente esse 0 nosso foco. Segundo Adam Crawford e Anthea Hucklesby ${ }^{28}$, a quantidade de normas nessa área levanta muitos questionamentos, muito especialmente sobre sua legitimidade. Para os autores, essas questões "exigem um exame conceitual rigoroso", além de convocarem "nossa atenção ao pensarmos em maneiras de regular melhor o comportamento das pessoas e promover a conformidade com as normas sociais vigentes".

Feito o destaque, tratemos agora, pois, ainda que sucintamente - dada a natureza ensaística da presente pesquisa -, dos afluentes que nos despertaram mais o interesse no processo de recolha da bibliografia com a qual nos deparamos. É preciso saber ao certo quais as principais providências que o empresariado deve efetivar para exercer uma administração comprometida com os princípios enunciados pelos órgãos citados. Como são muitos os programas de compliance, optamos por seguir a linha já traçada por Adán Nieto Martín ${ }^{29}$, um autor cuja obra é recorrentemente lembrada pelos que também enfrentam o tema. Serão, portanto, as reflexões do catedrático da Universidade de Castilla la Mancha o nosso principal referencial teórico a partir daqui.

Em primeiro lugar, tem sido apontado como imprescindível, como é evidente, a nomeação de um responsável, uma pessoa física, alguém comprometido com "a administração do risco". A partir disso, impõese ainda "estabelecer um sistema de documentação, análise de riscos, estabelecer normas de conduta, etc." ${ }^{30}$ Tentar antecipar-se, no máximo possível, aos problemas que eventualmente imponham inconvenientes legais ao regular funcionamento da empresa é o que se pretende com as

28 CRAWFORD, Adam; HUCKLESBY, Anthea (ed.). Legitimacy and compliance in criminal justice. New York: Routledge, 2013. p. 4. Tradução livre.

29 MARTÍN, Adán Nieto. Problemas fundamentales del cumplimiento normativo en el derecho penal. KUHLEN, Lothar; MONTIEL, Juan Pablo; URBINA GIMENO, Íñigo Ortiz de. Compliance y teoría del derecho penal. Madrid: Marcial Pons, 2013.

30 Idem, p. 24. Tradução livre. 
providências referenciadas. A figura do administrador nomeado especificamente para tal função proporciona que as cobranças, por melhorias ou por responsabilização, estejam concentradas naquela pessoa, evitando uma pulverização e a perda do foco.

Eis o compliance officer, a quem se incumbe de "criar regras e aprimorá-las permanentemente, apoiar a direção da empresa, inclusive nos processos negociais, fornecer aconselhamento preventivo e treinamento aos integrantes da organização empresarial, introduzir e coordenar os meios de controle para manter o respeito às normas do programa, detectar antecipadamente os desvios, informar frequentemente aos conselhos de direção acerca da situação do programa, de novos riscos identificados e das medidas preventivas, além de executar e/ou coordenar investigações internas e tomar, junto com os diretores, medidas disciplinares punitivas e as destinadas a eliminar os âmbitos de vulnerabilidade da empresa”. ${ }^{31}$

Em segundo lugar, seria preciso instituir uma espécie de governo corporativo, uma estrutura em que se possibilitem mecanismos que limitem a atuação tanto de dirigentes quanto dos demais funcionários da empresa. ${ }^{32}$ Assim entendido, o exercício do poder, mesmo em ambiente de natureza particular, precisa de barreiras contra o arbítrio. Com amparo em William S. Laufer ${ }^{33}$, a perspectiva de Adán Nieto Martín ${ }^{34}$ é a de que,

${ }^{31}$ LOBATO, José Danilo Tavares; MARTINS, Jorge Washington Gonçalves. Considerações preliminares acerca da responsabilidade criminal do compliance officer. Boletim do Instituto Brasileiro de Ciências Criminais, São Paulo, v. 24, n. 284, jul., 2016. p. 12. Os autores se amparam em: MOOSMAYER, Klaus. Anforderungen an den Compliance-Beauftragten. ROTSCH, Thomas (org.). Criminal Compliance. Baden-Baden: Nomos, 2015. p. 209. Recomenda-se ainda: PLANAS, Ricardo Robles. El responsable de cumplimiento («Compliance Officer») ante el Derecho penal. In: SILVA SÁNCHEZ, Jesús-María (Dir.) Criminalidad de empresa y compliance - Prevención y reacciones corporativas. Barcelona: Atelier, 2013. pp. 319-331.

32 BENEDETTI, Carla Rahal. Criminal Compliance: Instrumento de Prevenção Criminal Corporativa e Transferência de Responsabilidade Penal. Revista de Direito Bancário e do Mercado de Capitais, São Paulo, v. 59, jan. 2013. p. 315.

33 LAUFER, William S. Corporate Bodies and Guilty Minds - the failure of corporate criminal liability. Chicago: University of Chicago Press, 2006.

34 MARTíN, Adán Nieto. Problemas fundamentales del cumplimiento normativo en el derecho penal. KUHLEN, Lothar; MONTIEL, Juan Pablo; URBINA GIMENO, Íñigo Ortiz de. Compliance y teoría del derecho penal. Madrid: Marcial Pons, 2013. p. 24. Tradução livre. 
"quando se pensa em como controlar os administradores ou os postos mais elevados de direção com o fim de que não cometam infrações, resulta imprescindível contar com um órgão independente do poder empresarial, de outro modo, o controle sobre a cúpula da empresa não resultará crível”.

Depois, espera-se a existência de um código de ética que vincule a dinâmica de funcionamento da empresa, "onde se consegue o compromiso de luta contra a corrupção, a condenação de práticas restritivas da concorrência, a proteção de dados, etc." ${ }^{35}$. Como constatado por Adán Nieto Martín ${ }^{36}$, "a execução dos códigos éticos tem levado à criação de novos órgãos, como a Comissão do Código, Ethics Board, etc. E tem surgido cargos, como o ethics officer, que cumprem funções semelhantes aos compliance officer". Tem-se, com isso, mais uma das iniciativas que fazem parte do processo de fomento de "uma cultura da legalidade na empresa" ${ }^{37}$.

Enrique Bacigalupo ${ }^{38}$ faz questão de enfatizar as consequências negativas da falta de ética no meio empresarial. Os abusos praticados pelas gestões não são pautados por tais valores; além disso, são capazes de provocar um significativo (e, evidentemente, não desejado) descontrole do sistema financeiro mundial. O autor, referindo-se à crise que eclodiu no ano de 2008, aduz ainda que na crise financeira "não só se fala de economia e problemas estruturais do sistema econômico e financeiro, senão também de questões de legalidade, de ilegalidades e de debilidades éticas". A causa da crise, portanto, estaria vinculada também a um "distanciamento "dos fundamentos éticos".

Outra providência importante é a disponibilização do mecanismo da auditoria interna - uma iniciativa voltada para a identificação de possíveis desvios de comportamento de quaisquer dos vinculados à empresa. Pelas normas contidas na Statement on Auditing Standards (SAS No 78), ${ }^{39}$

35 Ibidem. Tradução livre.

36 Ibidem. Tradução livre.

37 Idem, p. 25. Tradução livre.

38 BACIGALUPO, Enrique. Compliance y Derecho penal. Navarra: Aranzadi, 2011. p. 13-16. Tradução livre.

39 MARTÍN, Adán Nieto. Problemas fundamentales del cumplimiento normativo en el derecho penal. KUHLEN, Lothar; MONTIEL, Juan Pablo; URBINA GIMENO, Íñigo Ortiz de. Compliance y teoría del derecho penal. Madrid: Marcial Pons, 2013. p. 25. 
emitida em 1995 pelo Auditing Standards Board do American Institute of Certifed Public Accountants, tem-se que "o controle interno é um processo - afetado pelo conselho de diretores da entidade, gerência e demais envolvidos - designado para proporcionar uma razoável segurança em relação ao sucesso dos objetivos das seguintes categorias: (a) segurança da informação financeira, (b) efetividade e eficiência das operações, e (c) cumprimento das leis e regulações aplicáveis" ${ }^{40}$.

A adesão a programas de certificação de qualidade também tem sido apresentada como um ingrediente importante nesse processo que intenciona evitar uma incidência do direito penal sobre o funcionamento das pessoas coletivas. ${ }^{41}$ A International Organization for Standardization (ISO), que é uma das maiores e mais conhecidas organizações a desenvolver normas de auxílio à implantação e ao funcionamento de uma gestão qualificada, "cria documentos que fornecem requisitos, especificações, diretrizes ou características que podem ser usadas consistentemente para garantir que materiais, produtos, processos e serviços sejam adequados para a finalidade" 42 .

Toda essa parafernália, constituída de mecanismos internos de vigilância, controle e responsabilização ${ }^{43}$ - muitas vezes sobrepostos que acabamos de passar em revista de maneira sucinta, ao mesmo tempo que intenciona proporcionar alternativas à incidência do direito penal, está sobretudo focada para garantir o regular funcionamento das pessoas coletivas. Em alguns países, como na Espanha, mesmo que não se consiga evitar tal invasiva incidência, a existência desses instrumentos pode levar

40 Disponível em: http://www.abaco.ec/equal/ipaper/sas-0078.doc. Acesso em 22 mar. 2018. Tradução livre.

41 BOCK, Dennis. Compliance y deberes de vigilancia en la empresa. KUHLEN, Lothar; MONTIEL, Juan Pablo; URBINA GIMENO, Íñigo Ortiz de. Compliance y teoría del derecho penal. Madrid: Marcial Pons, 2013. p. 107.

42 Disponível em: https://www.iso.org/standards.html. Acesso em 23 mar. 2018.

43 Adán Nieto Martín assegura que "los planteamientos de la ética empresarial y del voluntarismo jurídico están sin duda alguna en el ADN de las Guidelines y más concretamente de los programas de cumplimiento". Com amparo em Braithwaite, o autor então conclui que "en la actualidade puede decirse que se trata de estrategias complementarias, confluyentes, en el control del comportamiento colectivo desviado”. MARTÍN, Adán Nieto. La responsabilidad penal de las personas jurídicas: un modelo legislativo. Madrid: Iustel, 2008. p. 221; BRAITHWAITE, John. The new regulatory state and the transformation of criminology. British Journal of Criminology, n. 40, pp. 222-238, 2000. 
à atenuação ou até mesmo à exclusão da responsabilização penal. ${ }^{44}$ Tais possibilidades, aliás, dentre outras nuances, podem ser encontradas nos artigos 31 bis, 31 ter, 31 quater, 31 quinquies, do Código Penal espanhol.

Em Portugal, tem-se, por exemplo, o artigo 11, número 6, do código penal, que prescreve: "a responsabilidade das pessoas colectivas e entidades equiparadas é excluída quando o agente tiver actuado contra ordens ou instruções expressas de quem de direito". ${ }^{45}$

No Brasil, a Lei n. ${ }^{\circ}$ 12.846/2013, que "dispõe sobre a responsabilização administrativa e civil de pessoas jurídicas pela prática de atos contra a administração pública, nacional ou estrangeira", em seu artigo $7^{\circ}$, inciso VIII, prescreve que "serão levados em consideração na aplicação das sanções (...) a existência de mecanismos e procedimentos internos de integridade, auditoria e incentivo à denúncia de irregularidades e a aplicação efetiva de códigos de ética e de conduta no âmbito da pessoa jurídica”. O Regulamento n. ${ }^{\circ} 8.420 / 2015$, no artigo 41, prescreve os requisitos para a admissibilidade dos programas de integridade das empresas.

Assim, não foi por acaso que, no início do capítulo, mencionamos a proliferação de normas desse tipo. Uma incursão, ainda que palmar, na bibliografia sobre o assunto, leva-nos inevitavelmente a concluir que, atualmente, são muitos os recursos à mão do empresariado. Usar todo o potencial da empresa para fazer frente à sofisticada competitividade que a modernidade nos impôs exige disciplina e uma aguçada capacidade de adaptação às eventuais adversidades. Esses mecanismos internos, que na sua maioria são de naturezas essencialmente empresarial e laboral, ${ }^{46}$

44 A legislação em França e nos Estados Unidos, por exemplo, possibilita até mesmo a não promoção processual penal contra as pessoas coletivas, consagrando-se o princípio da oportunidade nesse âmbito. ANTUNES, Maria João. Privatização das investigações e compliance criminal. Revista Portuguesa de Ciência Criminal, Coimbra, ano 28, n. 1, jan-abr, 2018. p. 120-121.

45 Sobre a perspectiva portuguesa, com uma análise crítica do artigo 11 do código penal e da jurisprudência, recomenda-se: BRITO, Teresa Quintela de. Relevância dos mecanismos de 'compliance' na responsabilização penal das pessoas colectivas e dos seus dirigentes. Anatomia do crime - revista de Ciências Jurídico-Criminais, Coimbra, n. 0, jul.-dez., pp. 75-91, 2014.

46 Como antevisto, são muitos os recursos à mão do empresariado, podendo os programas de compliance assumir modelos diversos a depender da determinação legal. Manuel Gómez Tomillo, por exemplo, constata que "o Direito alemão asume um modelo administrativo sancionador para impor, de alguma 
servem para manter no radar da pessoa coletiva comportamentos que podem vir a comprometer não apenas seu regular funcionamento, mas principalmente sua possibilidade de continuar a existir legalmente.

Não temos dúvidas, portanto, de que a adesão aos programas de compliance é um caminho sem volta para o empresariado, sobretudo para aqueles à frente de empresas de médio e grande porte. O fato é que as pessoas coletivas nunca estiveram tão em evidência, exigindo-se delas não apenas um comportamento omissivo quanto à prática de violações, sobretudo aos direitos humanos, mas efetiva proatividade no sentido de não permitir que elas ocorram no âmbito de sua influência direta. Essa é uma das atuais preocupações de Adán Nieto Martín, para quem os estados deveriam se dedicar a obrigar as empresas a criarem "diligências devidas" com o intuito de evitar as mencionadas violações. ${ }^{47}$

Embora disseminadas, essas normas não são propriamente uma novidade. Logo, estabelecer regras de conduta e exigir o respeito a elas não é rigorosamente uma inovação. O modo como as empresas atualmente lidam com essa dinâmica normativa é que sofreu significativas adaptações. A criação de um canal de denúncias e a possibilidade de uma investigação interna ${ }^{48}$ por exemplo, abrem possibilidades que, a depen-

forma coativamente, deveres de compliance nas personas jurídicas (e o ordenamento italiano no marco concreto de luta contra a corrupção). Pelo contrário, o Direito projetado espanhol e o Corpus Iuris optam por um modelo penal". TOMILLO, Manuel Gómez. Compliance penal y política legislativa - el deber personal y empresarial de evitar la comisión en el seno de las personas jurídicas. Valencia: Tirant lo blanch, 2016. p. 95. Tradução livre.

47 MARTÍN, Adán Nieto. Compliance programs en materia de derechos humanos. Colóquio Direito penal económico em mudança. Auditório da Faculdade de Direito da Universidade de Coimbra, 20 mar. 2018.

48 ANTUNES, Maria João. Privatização das investigações e compliance criminal. Revista Portuguesa de Ciência Criminal, Coimbra, ano 28, n. 1, jan-abr, 2018. p. 122; RIOS, Rodrigo Sánchez; MACHADO, Allian Djeyce Rodrigues. Criminalidade intraempresarial, sistemas de denunciação interna e suas repercussões na seara penal: o fenômeno do whistleblowing. Revista do Instituto Brasileiro de Ciências Criminais, São Paulo, ano 25, n. 137, 2017. Vale também: RAGUÉS I VALLĖS, Ramon. Whistleblowing: una aproximación desde el derecho penal. Madrid: Marcial Pons, 2013; RAGUÉS I VALLĖS, Ramon. Los procedimientos internos de denuncia como medida de prevención de delitos en la empresa. SILVA SÁNCHEZ, Jesús-María (Dir.). Criminalidad de empresa y compliance - Prevención y reacciones corporativas. Barcelona: Atelier, 2013. 
der das circunstâncias, preocupam-nos. Elas podem servir para que seja enquadrada uma filial que deliberadamente não cumpre o programa de sua matriz, como também podem servir para apurar infrações com sérias consequências à vida de seus empregados. ${ }^{49}$

Daí que os programas de compliance podem funcionar como uma espécie de antecâmara do processo penal. ${ }^{50}$ Só que com uma dinâmica de produção de provas dirigida por particulares, com regras de garantias pessoais alegadamente menos rígidas, pois subordinadas aos direitos empresarial e laboral, o que pode vir a ser um risco, tendo em vista que, nesse tipo de persecução, é provável que exista interferência em direitos fundamentais. Ao permitirmos, sem uma necessária reflexão crítica, a fruição desse movimento, estaríamos adotando um comportamento negligente perante a tendência de uma privatização do processo penal. ${ }^{51}$ É preciso avaliar como tudo isso pode se coadunar com os valores democráticos.

\section{A PROdUÇÃo de PROVA No ÂMBito dos PROGRAMAS DE COMPLIANCE E A POTENCIAL IMPLICAÇÃO DE DIREITOS E GARANTIAS FUNDAMENTAIS: É POSSÍVEL UMA PRIVATIZAÇÃO DE UM DEVER TRADICIONALMENTE ESTATAL?}

São muitos os trabalhos dedicados às nuances da produção de prova no âmbito de um processo penal que se pretende democrático..$^{52}$ Por

49 Devo a reflexão do presente parágrafo à Senhora Professora Doutora Maria João Antunes, que, no encontro do dia 22/3/2018, em Coimbra, embora não tenha afirmado exatamente aquilo o que escrevemos - razão pela qual já nos desculpamos por eventuais equívocos interpretativos -, levou-nos a refletir da maneira crítica sobre o assunto.

ANTUNES, Maria João. Idem, p. 127.

51 A ideia é, originariamente, devida à Senhora Professora Doutora Maria João Antunes. Vide nota 48. Mais em: ANTUNES, Maria João. Privatização das investigações e compliance criminal. Revista Portuguesa de Ciência Criminal, Coimbra, ano 28, n. 1, jan-abr, 2018. Também no sentido exposto: MARTÍN, Adán Nieto. Problemas fundamentales del cumplimiento normativo en el derecho penal. KUHLEN, Lothar; MONTIEL, Juan Pablo; URBINA GIMENO, Íñigo Ortiz de. Compliance y teoría del derecho penal. Madrid: Marcial Pons, 2013. p. 46-48.

52 Para uma análise rigorosa e aprofundada a respeito, partindo-se da perspectiva do direito português, recomenda-se: COSTA ANDRADE, Manuel da. Sobre as proibições de provas em processo penal. Coimbra: Coimbra, 2013. Esse 
óbvio, utilizaremos alguns deles ao longo do presente capítulo, tendo em vista que são parâmetros fundamentais ao debate proposto, mas não nos debruçaremos pormenorizadamente sobre esse específico tema. Não por entendermos que não seja importante - muito longe disso -, mas porque nos interessa esse tipo de atividade nas investigações promovidas por intermédio dos programas de compliance. A atuação de particulares no exercício desse ofício e a sua potencial interferência negativa em direitos e garantias fundamentais são os nossos principais objetos de preocupação.

Como sabemos, inúmeras são as possibilidades de produção de provas numa investigação presidida pelo Estado. Se utilizarmos como parâmetro o Código de Processo Penal português, por exemplo, a regra é a de que "são admissíveis as provas que não forem proibidas por lei" (artigo $125 .^{\circ}$ ). Admitem-se, portanto, provas testemunhais, declarações (do arguido, do assistente e das partes civis), acareações, reconhecimentos, reconstituições do fato, perícias e documentos variados. Nessa dinâmica, para garantir "a realização da justiça e a descoberta da verdade material", tolera-se a utilização de medidas de coação, desde que calibradas pela legalidade, necessidade, adequação, proporcionalidade e subsidiariedade..$^{53}$

tema da proibição, aliás, foi pioneiramente introduzido em Portugal por Jorge de Figueiredo Dias: FIGUEIREDO DIAS, Jorge de. Revisitação de algumas ideias-mestras da teoria das proibições da prova em processo penal (também à luz da jurisprudência constitucional portuguesa). Revista de Legislação e de Jurisprudência, ano 146, n. 4000, set.-out., 2016. pp. 3-16. Originalmente em: FIGUEIREDO DIAS, Jorge de. Direito Processual Penal. Coimbra: Coimbra, 1974. Uma análise histórica da prova em matéria criminal no espaço europeu, recomenda-se: MITTERMAYER, Carl Joseph Anton. Tratado da prova em matéria criminal - ou exposição comparada dos princípios da prova em matéria criminal, etc., de suas aplicações diversas na Alemanha, França, Inglaterra, etc. $3^{\mathrm{a}}$ ed. Trad. Alberto Antonio Soares. Rio de Janeiro: Jacinto Ribeiro dos Santos, 1917. p. 22 ss.

53 ANTUNES, Maria João. Direito processual penal. Coimbra: Almedina, 2016. p. 120-135. Muito longe de advogarmos o imobilismo do sistema de controle estatal, mas não se pode deixar de destacar, sobretudo no Brasil, de uma incipiente cultura democrática, que o argumento "[d]a realização da justiça e a descoberta da verdade material", mesmo com a calibragem apontada, parece-nos uma porta generosamente aberta para que, como nos diz Aury Lopes Jr., "os movimentos repressivistas e as ideologias decorrentes" continuem fazendo com que, “cada vez mais, a 'liberdade seja 'provisória' (até o CPP consagra a liberdade provisória...) e a prisão cautelar (ou mesmo definitiva) uma regra”. LOPES JR., Aury. Direito processual penal. 9. ed. São Paulo: Saraiva, 2012. p. 42-43. 
O empenho do empresariado em tentar neutralizar ameaças ao regular funcionamento da pessoa coletiva pode vir a ultrapassar limites importantes numa democracia. Logo, pode vir a provocar graves violações a valores consagrados convencional e constitucionalmente. Para Jordi Gimeno Beviá54, "em certas ocasiões podem se confundir as investigações internas com situações nas quais a pessoa jurídica, para controlar tudo o que acontece dentro dela, coloca, em suas dependências, câmaras, microfones, intercepta as telecomunicações de seus empregados, etc.". Ainda que se consiga tal desiderato, segundo o autor, "podem supor uma vulneração muito importante de direitos fundamentais dos trabalhadores”.

Não há de ser difícil concluir que, em determinadas circunstâncias, as consequências práticas de uma investigação interna podem ser mais gravosas do que uma presidida pelo próprio Estado. Perceba-se, por exemplo, que despedir uma pessoa por conta de uma infração disciplinar, tal como uma violação ao código de ética da empresa, dando-se publicidade disso, tem o potencial de ser mais prejudicial à sua vida social do que se aplicada uma pena de multa por conta da prática de um crime. ${ }^{55}$ Nessas circunstâncias, perder o emprego, através do qual o sujeito sustenta a si e à própria família, tendo ficado malvisto no mercado de trabalho, possui um potencial de impacto mais pesaroso sobre a dignidade humana. ${ }^{56}$

José Joaquim Gomes Canotilho e Vital Moreira ${ }^{57}$ explicam que os "interesses do processo criminal encontram limites na dignidade humana (art. $1^{\circ}$ [da Constituição da República portuguesa - doravante

54 BEVIÁ, Jordi Gimeno. Compliance y proceso penal. El proceso penal de las personas jurídicas - adaptada a las reformas del CP LECRIM, circular FGE 1/2016 y jurisprudencia del TS. Navarra: Aranzadi, 2016. p. 227. Tradução livre.

55 No caso da legislação portuguesa, por exemplo, veja-se o art. 137 do código penal (homicídio por negligência), que, apesar de ter a vida como bem juridicamente tutelado, prescreve como pena alternativa à privação da liberdade a possibilidade de uma multa.

56 Valor esse que, por ser a base de um Estado de direito democrático, está consagrado, entre outros instrumentos normativos, na Declaração Universal dos Direitos Humanos (1948), na Convenção Europeia de Direitos Humanos (1950), na Convenção Americana sobre Direitos Humanos (1969) e na Carta Africana de Direitos Humanos e dos Povos (1981).

57 GOMES CANOTILHO, J. J.; MOREIRA, Vital. Constituição da República Portuguesa Anotada - v. I. $4^{\text {a }}$ ed. Coimbra: Coimbra Editora, 2014, p. 524. 
CRP]) e nos princípios fundamentais do Estado de direito democrático $\left(\operatorname{art} .2^{\circ}\right)$, não podendo, portanto, valer-se de actos que ofendam direitos fundamentais básicos". Corolários do respeito à dignidade humana, outros paradigmas $^{58}$ historicamente conquistados, como a intimidade da vida privada, o nemo tenetur se ipsum acusare, a presunção de inocência, o contraditório, a ampla defesa, entre outros, colocam-se também à prova diante dessa "nova" (e invasiva) atividade empresarial.

Nesse passo, antes de prosseguirmos, merece ser enfatizado o fato de que, ao celebrarem o contrato de trabalho, os empregados se comprometem com o seu regular cumprimento. O gesto desencadeia uma série de obrigações recíprocas, entre as quais a aceitação da autoridade patronal no exercício da atividade contratada. São os empregados, portanto, subordinados aos dirigentes com os quais se relacionam na estrutura hierarquizada da empresa. Assumem, a partir daí, entre outros, os deveres de zelo, cooperação, lealdade e obediência. ${ }^{59}$ Portanto, não é por acaso que a percepção que se tem é a de que os programas de compliance podem acabar assumindo a característica de antecâmara do processo penal.

Afinal, como sopesar as obrigações laborais dos empregados com os direitos e garantias consagrados no ordenamento democrático? Ainda que em contexto diverso, aqui valem, por analogia, as lições de Jorge de Figueiredo Dias e Manuel da Costa Andrade ${ }^{60}$. Para os autores, "a obrigação legal de prestar informações no âmbito de um processo de fiscalização e supervisão não se confunde com - nem prejudica - [por exemplo] o direito ao silêncio que assiste ao arguido no âmbito de um eventual processo sancionatório posterior (criminal ou contra-ordenacional), designadamente, no âmbito de interrogatório perante as autoridades

58 No sentido kuhniano: KUHN, Thomas S. A estrutura das revoluções científicas. Trad. Beatriz Vianna Boeira e Nelson Boeira. 12a ed. São Paulo: Perspectiva, 2013.

59 Para aprofundar essas questões, recomenda-se: CORDEIRO, António Menezes. Manual de Direito do trabalho. Coimbra: Almedina, 1991; e AMADO, João Leal. Contrato de trabalho: noções básicas. Coimbra: Almedina, 2016.

60 FIGUEIREDO DIAS, Jorge; COSTA ANDRADE, Manuel da; COSTA PINTO, Frederico de Lacerda da. Supervisão, direito ao silêncio e legalidade da prova. Coimbra: Almedina, 2009. p. 49. 
competentes". E concluem: "Aí valem, em todo a sua plenitude, as regras processuais que prevêem o direito ao silêncio do arguido”.

Os investigadores possuem, muito por conta dessas regras laborais, uma relação de maior poder de pressão junto aos empregados, o que se acentua sobre os menos graduados. Há, nesses casos, uma relação de certa ascendência hierárquica dos que investigam sobre os que são investigados, o que, como dissemos, demanda preocupação pelas potenciais interferências indevidas em direitos e garantias fundamentas. Como se não bastasse, esses investigadores ainda têm acesso desembaraçado a uma série de documentos - tais como os relacionados com a vida particular e profissional dos empregados - que um agente estatal normalmente teria de estar de posse de uma ordem judicial para consegui-los.

Perceba-se que na perspectiva de Anabela Miranda Rodrigues ${ }^{61}$, os programas de compliance, que, para ela, desenvolveram-se independentes do direito penal, apresentam problemas para este ramo do direito. Segundo a catedrática de Coimbra, esses programas "podem ser usados como uma armadilha para as empresas e levar à reversão do ônus da prova ou podem servir de fachada, o que reduz a responsabilidade corporativa. Os programas de conformidade devem ser eficazes e mantidos vivos e totalmente operacionais. A chave para superar esses problemas é evitar seu descrédito. É necessário aumentar sua credibilidade através de órgãos de conformidade independentes, profissionais e participativos e vinculá-los à ética empresarial deliberativa e à democracia das partes interessadas”.

Constata-se, ademais, que o controle judicial não é incisivamente garantido na dinâmica da investigação interna. ${ }^{62}$ As cautelas podem estar vinculadas a outros interesses. Ramon Ragués i Vallès ${ }^{63}$ aponta, por exemplo, que - agora dizemos nós: pelas cautelas que os direitos funda-

61 RODRIGUES, Anabela Miranda. Compliance programs and corporate criminal compliance. PoLaR - Portuguese Law Review, v. 2, n. 1, jan., 2018. p. 1. (tradução livre)

62 Embora, como é óbvio, possa vir a ser convocado pelos que se sentirem prejudicados.

63 RAGUÉS I VALLÈS, Ramon. Los procedimientos internos de denuncia como medida de prevención de delitos en la empresa. SILVA SÁNCHEZ, Jesús-María (Dir.). Criminalidad de empresa y compliance - Prevención y reacciones corporativas. Barcelona: Atelier, 2013. p. 189. 
mentais impõem - a investigação dos agentes estatais é geralmente mais lenta do que aquela presidida pela empresa. Em virtude das implicações penais e dos prejuízos diversos que poderiam sofrer, da perspectiva do autor, a comunicação de eventuais desvios às autoridades ficaria a cargo da conveniência empresarial. Entretanto, nos casos de comunicação, identificados comportamentos prescritos como crime, aí sim, atuaria o Estado.

Por outro lado, pese-se que condicionar a ideia de respeito às regras mínimas de uma investigação no âmbito dos programas de compliance unicamente à presença de uma espécie de juiz de garantias (dentro de uma lógica processual de reserva de juiz) poderia ser encarado como uma pressuposição de falta de boa-fé na relação jurídica entre "iguais" ${ }^{64}$, ou seja, na relação que se estabelece entre os investigadores e os investigados, ambos encarados como particulares. Ambos, portanto, "livres" para se socorrerem do judiciário nos casos de eventuais abusos. Se assim não fosse, seria inverter a lógica de que a boa-fé há de ser pressuposta na dinâmica social e na própria estrutura geral do ordenamento jurídico. ${ }^{65}$

Ocorre que essas investigações, como sabemos, auxiliam na formação do convencimento do responsável pela resolução do conflito. Tem-se, portanto, uma tarefa necessária para que se possa definir, se for o caso, quais responsabilidades devem recair sobre a pessoa investigada. A atividade probatória serve justamente para que se atinja esse perseguido desiderato. Daí que a produção de provas ganha contornos preocupantes no âmbito dos programas de compliance. Dito de outra maneira: teremos provas recolhidas sob a égide de um sistema particular que, uma vez entregues ao Estado, tendem a ser decisivas na formação da convicção sobre a permanência ou não do status de inocência do investigado.

64 Na persecução penal, tal como a conhecemos atualmente, não há propriamente "iguais", vez que, quem, normalmente, acusa (e mesmo quem julga) atua enquanto representante do Estado contra um particular.

O mesmo raciocínio poderia ser projetado para os centros de mediação e arbitragem, não necessariamente vinculados ao poder judiciário. Mas esse não nos parece um ponto absolutamente resolvido, constituindo-se, portanto, no atual estágio de nossa pesquisa, numa conclusão provisória, aberta, como é evidente, ao contraditório. Aprofundadamente sobre a boa-fé e a necessidade de proteção da confiança, por todos, recomenda-se: CORDEIRO, António Meneses. Da boa-fé no direito civil. Coimbra: Almedina, 2015. 
Apesar de todas as ressalvas que podem (e devem) ser feitas nessa temática, o uso de particulares em investigações não tem sido considerado, de per si, como ilegítimo. A propósito disso, na legislação portuguesa tem-se esse tipo de possibilidade na Lei n. ${ }^{\circ}$ 101/2001, de 25 de agosto, que estabelece o regime jurídico das ações encobertas para fins de prevenção e investigação criminal. ${ }^{66}$ Assim, também no âmbito da empresa, a presença de investigadores particulares não há de se constituir como uma providência ilegítima ou ameaçadora dos direitos fundamentais, desde que, como nos parece óbvio, se proceda "mediante meios legítimos para a obtenção da informação". ${ }^{67}$

No Brasil, por sua vez, a participação efetiva de particulares em investigação oficial recebeu a atenção do legislador penal a partir do advento da Lei 13.432/2017, de 11 de abril, onde dispôs sobre o exercício da profissão de detetive particular. Entre outras coisas, nela se estabeleceu que "o detetive particular pode colaborar com investigação policial em curso, desde que expressamente autorizado pelo contratante" (art. $5^{\circ}$ ); “o aceite da colaboração ficará a critério do delegado de polícia, que poderá admiti-la ou rejeitá-la a qualquer tempo" (Parágrafo Único do art. $5^{\circ}$ ). Abre-se uma oportunidade de estruturação de verdadeiras empresas nessa área, o que reforça a preocupação com a privatização do processo penal.

Apesar das obrigações que recaem sobre os empregados, algumas das quais mencionamos há pouco, bem como da implantação legítima dos programas de compliance, existem esferas de proteção dos direitos dos empregados que não podem ser ultrapassadas por uma investigação interna. ${ }^{68}$

66 Em especial nos artigos $1 .^{\circ}$, número 2, e 4. ${ }^{\circ}$. No Brasil não há previsão legal específica para tal, razão pela qual se pressupõe que a prática esteja proibida. Apesar disso, a utilização de particular "encoberto" tem sido objeto de intensa discussão na doutrina brasileira. Repercussões em: PORCIÚNCULA, José Carlos. Delator não pode incitar interlocutor a cometer crimes para denunciá-los depois. Revista Consultor Jurídico, Brasília, jul., 2017. Disponível em: https://www.conjur.com.br/2017-jul-04/jose-porciuncula-ilegalidadesgravacao-joesley-batista. Acesso em 30 abr. 2018.

ESTRADA I CUADRAS, Albert; ANGLÍ, Mariona Llobet. Derechos de los trabajadores y deberes empresario. SILVA SÁNCHEZ, Jesús-María (Dir.). Criminalidad de empresa y compliance - Prevención y reacciones corporativas. Barcelona: Atelier, 2013. p. 220-221. Tradução livre.

68 Notadamente que existem limites semelhantes para uma investigação estatal, no entanto, pela natureza ensaística da presente pesquisa, fomos direto ao 
A intimidade da vida privada é uma delas. Não podem os investigadores, por regra, sobretudo quando não guardam relação direta com a atividade profissional, dirigir questionamentos sobre a vida íntima, sentimental, sexual ou ideológica dos investigados. Segundo Albert Estrada i Cuadras e Mariona Llobet Anglí́, , esse tipo de indagação estaria proibida, "tanto pelo respeito ao direito à intimidade, como pela influência do princípio que proscreve a discriminação por essas causas”.

Veja-se ainda o âmbito de limitação do nemo tenetur se ipsum acusare ${ }^{70} \mathrm{o}$ que há de nos levar a afirmar, junto com Manuel da Costa Andrade $^{71}$, que "os deveres de colaboração subsistentes em ramos de direito exteriores ao processo penal não podem projectar-se sobre o processo penal em provas (coercivamente) auto-incriminatórias". Segundo o autor, que em seu texto trata de uma questão de autoincriminação em recolha de provas no âmbito de uma investigação tributária, "a comunicação entre os procedimentos-ambiente e o processo penal é interrompida pela estrita vinculação ao fim dos dados auto-incriminatórios resultantes do cumprimento dos deveres de colaboração e cooperação que ordenamentos como o direito tributário [também o laboral ou empresarial] fazem impender sobre o cidadão".

De todo modo, os argumentos até aqui expostos nos permitem concluir que os direitos de defesa em processo investigativo, se comparados com os direitos sociais ínsitos ao ambiente de trabalho, que é, aliás,

que constitui o centro de nossas atenções.

69 ESTRADA I CUADRAS, Albert; ANGLÍ, Mariona Llobet. Derechos de los trabajadores y deberes empresario. SILVA SÁNCHEZ, Jesús-María (Dir.) Criminalidad de empresa y compliance - Prevención y reacciones corporativas. Barcelona: Atelier, 2013. p. 222. Tradução livre. Os autores se amparam em: CARDONA RUBERT, María Belén. El derecho a la intimidad en la relación laboral. Ius et Praxis, Chile, año 4, (2), pp. 107-134, 1998.

70 Nesse particular, interessante é a análise encontrada em: PAIS, Ana. Os programas de compliance e o risco de privatização do processo penal. Em especial, a problemática da 'prova emprestada' e o princípio do nemo tenetur se ipsum accusare. Boletim da Faculdade de Direito da Universidade de Coimbra - Estudos em homenagem ao Prof. Doutor Manuel da Costa Andrade, v. II, 2017. p. 671 ss.

71 Os colchetes são nossos. COSTA ANDRADE, Manuel da. Nemo tenetur se ipsum acusare e o direito tributário. Ou a insustentável indolência de um acórdão ( $\left.{ }^{\circ} 340 / 2013\right)$ do Tribunal Constitucional. Revista de Legislação e de Jurisprudência, ano $144^{\circ}, \mathrm{n}^{\circ} 3.989$, novembro-dezembro, 2014, p. 153. 
o habitat dos programas de compliance, estão em esferas mais próximas da dignidade humana, devendo, portanto, prevalecer. $^{72}$

No entanto, dada a existência de uma larga margem de discricionariedade, será imprescindível observar determinados limites para que se admita a implantação e o funcionamento legítimo dos inúmeros modelos de compliance atualmente existentes. Daí a necessidade de estarmos no âmbito daquilo que Ulrich Sieber ${ }^{73}$ classificou por "autorregulação regulada", também conhecida por "corregulação estatal e privada", que se constitui numa "fórmula mista ou intermediária entre autorregulação e regulação estatal, que se caracteriza por conceder uma margem de discricionariedade àqueles que devem especificar o programa e as fórmulas que usa para estimular ou pressionar para sua adoção”.

Por razões como essas, diretamente vinculadas à necessidade de respeito aos valores consagrados no ordenamento jurídico com os quais se vinculam, é possível encontrarmos quem afirme que os programas de compliance, apesar de sua natureza eminentemente privada, "na medida em que procuram respeitar a legalidade penal e neutralizar os riscos criminais, assumem uma certa natureza de ordem pública". ${ }^{74} \mathrm{~A}$ ser assim, as atividades que nós, pessoas físicas, levamos a cabo cotidianamente

72 Devo a presente reflexão à Senhora Professora Doutora Inês Fernandes Godinho, que, em encontro sob a coordenação da Senhora Professora Doutora Maria José Capelo, em 4/5/2018, na Casa da Jurisprudência, em Coimbra, abordou sucintamente o assunto. Ademais, dirá Ingo Wolfgang Sarlet que a dignidade humana "acaba por justificar (e até mesmo exigir) a imposição de restrições a outros bens constitucionalmente protegidos”. SARLET, Ingo Wolfgang. Dignidade da pessoa humana e direitos fundamentais na Constiuição Federal de 1988. 2. ed. Porto Alegre: Livraria do Advogado, 2002. p. 74.

SIEBER, Ulrich. Programas de 'compliance' en el derecho penal de la empresa. Una nueva concepción para controlar la criminalidad económica. Trad. Abanto Vásquez. El Derecho Penal Económico en la era Compliance. ARROYO ZAPATERO, Luis; NIETO MARTÍN, Adán (Dir.). Valencia: Tirant, 2013, p. 77. Tradução livre.

74 NEIRA, Ana María. La efectividad de los criminal compliance programs como objeto de prueba en el proceso penal. Política criminal. V. 11, n. 22 (Diciembre 2016), Art. 5, pp. 469-470. Tradução livre. Com amparo em: GOÑI SEIN, José Luis. Programas de cumplimiento empresarial (compliance programs): aspectos laborales. MIR PUIG, Santiago; CORCOY BIDASOLO, Mirentxu; GÓMEZ MARTÍN, Víctor (Dirs.); HORTAL IBARRA, Juan Carlos; VALIENTE IBÁÑEZ, Vicente (Coords.). Responsabilidad de la empresa y compliance. Programas de prevención, detección y reacción penal. Montevideo-Buenos Aires: B de F, 2014. p. 383. 
também estariam abarcadas por tal premissa, já que "também estamos submetidos ao cumprimento de certas regras de prudência: de controle do próprio corpo e de nosso âmbito de organização". ${ }^{75}$

Não obstante eventuais controvérsias, já que a fórmula apresentada acima não resolve nossos problemas, uma investigação nos domínios da pessoa coletiva, embora possua peculiaridades - como o fato de ser presidida por particulares -, deve guardar, tanto quanto possível, similaridades com as regras tradicionalmente esculpidas para uma persecução penal em ambiente que se pretende democrático. Movido por tal preocupação, Jordi Gimeno Beviá7 ${ }^{76}$, para quem "algumas empresas tratam de estabelecer certos paralelismos entre as garantias internas e as garantias legais", destaca que o conglomerado industrial alemão SIEMENS “dispõe que a investigação haverá de respeitar a presunção de inocência do empregado e os direitos do Comitê da Empresa (Work Council)".

É a partir desse cenário que percebemos o avanço da iniciativa privada sobre atividades normalmente vinculadas aos agentes públicos. Ensino, saúde, limpeza, iluminação, segurança, entre outras, são atividades sobre as quais as empresas nutrem significativos interesses, de modo que, atualmente, em muitos desses setores, tem se apresentado como tênue a linha destinada a separar o público do privado. Portanto, sobre a possibilidade de privatização (ou particularização) de deveres tradicionalmente estatais não restam dúvidas. Não só isso é possível como já é uma realidade. ${ }^{77}$ Nas ciências criminais, dada a incapacidade estatal de cumprir as promessas que historicamente têm sido feitas à sociedade, essa movimentação já nos parece despontar como uma tendência consolidada. ${ }^{78}$

75 LASCURAÍN, Juan Antonio. Los programas de cumplimiento como programas de prudencia penal. Revista Portuguesa de Ciência Criminal, Coimbra, ano 25, n. 1 a 4, jan.-dez., 2015. p. 96. Tradução livre.

76 BEVIÁ, Jordi Gimeno. Compliance y proceso penal. El proceso penal de las personas jurídicas - adaptada a las reformas del CP LECRIM, circular FGE 1/2016 y jurisprudencia del TS. Navarra: Aranzadi, 2016. p. 227. Tradução livre.

77 Vale a leitura de: DAMIÃO DA CUNHA, José Manuel. O conceito de funcionário, para efeito de lei penal e a "privatização" da administração Pública. Uma revisão do comentário ao art. $386 .^{\circ}$ do Código Penal - Comentário Conimbricense do Código Penal. Coimbra: Coimbra, 2008.

78 Ainda que em outro contexto, Aury Lopes Jr. adverte-nos: “cumpre destacar que o monopólio estatal de perseguir e punir está sendo questionado a cada 
No que se refere à privação da liberdade, esse tipo de fenômeno já está consolidado em diversos países que se intitulam democráticos. Nos Estados Unidos e no Brasil, ${ }^{79}$ apenas para ficarmos nesses dois exemplos, inúmeros estabelecimentos prisionais estão entregues à responsabilidade de empresas privadas. Além disso, sobretudo nos países em que é mais forte o medo pelo avanço de atividades terroristas, empresas de segurança privada proliferam..$^{80}$ Ocorre que, ultimamente, o que tem figurado como objeto de interesse é o processo de responsabilização. Para Adán Nieto Martíns ${ }^{81}$, "a responsabilidade penal das pessoas jurídicas é na realidade um exemplo de privatização de funções públicas”, o que não nos parece, por si só, algo absolutamente indevido.

Segundo o autor, "a ideia que se esconde atrás da responsabilidade penal é que a imposição de uma pena serve para motivar os dirigentes da pessoa jurídica a porem em marcha um sistema 'policial' interno que impeça a comissão de delitos como a corrupção, e que em caso de cometimento que se descubra". ${ }^{82}$ Não obstante não nos parecer, nesse primeiro momento, ilegítima a presença desse "sistema policial" interno, ele impõe medidas que não permitam qualquer abuso na busca pela responsabilização quando identificado algum tipo de desvio. Disso,

dia com mais força, com o implemento de princípios, como oportunidade e conveniência da ação penal, aumento do número de delitos de ação penal privada ou pública condicionada, e com as possibilidades de transação penal (plea bargaining). A justiça negociada configura uma perigosa e equivocada alternativa ao processo penal”. LOPES JR., Aury. Fundamentos do processo penal - introdução crítica. Lisboa: Rei dos Livros, 2016. p. 68.

79 Vejam-se, por exemplo: WACQUANT, Loïc. As prisões da miséria. Trad. André Telles. Rio de Janeiro: Zahar, 2011; WACQUANT, Loïc. Punir os pobres - a nova gestão da miséria nos Estados Unidos. Trad. Sérgio Lamarão. Rio de Janeiro: Revan, 2003; SILVA, José Adaumir Arruda da. A privatização de presídios - uma ressocialização perversa. Rio de Janeiro: Revan, 2016.

OLIVEIRA, Ariana Bazzano de. A guerra terceirizada: as empresas privadas de segurança e a 'guerra ao terror'. Carta Internacional, São Paulo, v. 5, n. 1, mar., 2010. pp. 64-77. Disponível em: https://cartainternacional.abri.org.br/ Carta/article/download/530/284. Acesso em 30 abr. 2018.

81 MARTÍN, Adán Nieto. La privatización de la lucha contra la corrupción. Cahiers de defense sociale - pour una politique criminelle humaniste, 2011-2012. p. 71. Disponível em: http://www.defensesociale.org/CAHIERS_2012/Cahiers_2011-2012_PDF.pdf. Acesso em 27 mar. 2018. Tradução livre.

82 Ibidem. Tradução livre. 
aliás, conforme veremos a seguir, dependerá a validade da prova, quando compartilhada com o processo penal.

Na perspectiva de Maria João Antunes ${ }^{83}$, “a cooperação privada na investigação criminal deve rodear-se de uma série de garantias que compensem os riscos que tais investigações geram". Segundo a autora, "por um lado, as investigações internas deverão obedecer às garantias básicas e irrenunciáveis do processo penal, o que mostra o quanto é relevante elaborar um código que regulamente as investigações internas; por outro, o direito processual penal só deverá valorar os meios de prova obtidos com respeito pelos direitos fundamentais".

Nesse contexto, sobre a produção da prova, pode-se dizer que a excessiva demanda aliada à limitada quantidade de juízes, sobretudo no caso de países como o Brasil, em que os recursos destinados ao funcionamento do judiciário não são propriamente abundantes, praticamente empurram o processo, sobretudo o criminal, para esse caminho. Já se fala, no âmbito do direito probatório, em um movimento de desjudicialização da prova.$^{84} \mathrm{~A}$ iminência de um cenário como esse, no qual os programas de compliance se apresentam com protagonismo, impõe-nos o debate e a apresentação de alternativas que, em vez de suplantar, devem reforçar os direitos de defesa e os valores democráticos.

\section{O compartilhamento (e o empréstimo) da prova com O PROCESSO PENAL DE PRETENSÃO DEMOCRÁTICA}

Formada a convicção sobre a responsabilidade de alguém no âmbito de um desses programas de compliance, a questão que nos norteia agora é saber se pode vir a ser legítimo o compartilhamento das provas

83 ANTUNES, Maria João. Privatização das investigações e compliance criminal. Revista Portuguesa de Ciência Criminal, Coimbra, ano 28, n. 1, jan-abr, 2018. p. 125-126.

84 MÜLLER, Julio Guilherme. Negócios processuais e desjudicialização da produção da prova - análise econômica e jurídica. São Paulo: Revista dos Tribunais, 2017. Devo a lembrança, sobre a discussão doutrinal atinente à desjudicialização da prova, à Senhora Professora Doutora Maria José Capelo, com quem tivemos encontro no dia 4/5/2018, na Casa da Jurisprudência, em Coimbra. 
ali recolhidas com um processo penal de pretensão democrática ${ }^{85} \mathrm{Em}$ apertada síntese: seria possível "utilizar, num determinado processo, os elementos de convicção formados em procedimento diverso e autônomo?" ${ }^{86}$ No fundo, levando-se em conta a ideia de unidade jurisdicional, além de razões de economia e celeridade ${ }^{87} \mathrm{o}$ compartilhamento de provas, em tese - e dito a traço grosso -, não deveria encontrar maiores resistências quando interessados órgãos de mesma natureza.

Ocorre que, de maneira geral, o problema que se coloca no presente capítulo diz respeito à possibilidade da circulação de provas entre órgãos de natureza bem diversa. Ou seja, não se trata apenas do fato de termos de um lado uma empresa privada e do outro uma entidade pública, mas de estarmos diante de uma dinâmica de produção de provas que é regida essencialmente por normas administrativas, contratuais, laborais e/ou empresariais, além de procedimentos (que podem afetar direitos fundamentais) presididos por particulares. É evidente, porém, que essas normas estão vinculadas à legalidade, mas numa margem de discricionariedade que nos preocupa quando se trata da responsabilização de alguém. ${ }^{88}$

85 Embora a questão do empréstimo da prova também esteja relacionada com a problemática proposta, nosso enfoque, conforme o próprio título do trabalho já indica, recairá sobre o compartilhamento, vez que, da nossa perspectiva, este último, pelas características que já delineamos no início deste trabalho, encontra-se em patamar diferenciado, ou seja, a prova compartilhada parecenos possuir, originalmente, um valor deficitário pela ausência de contraditório. De toda forma, tanto quanto possível, faremos considerações mais gerais, sem nos atermos especificamente a uma ou a outra expressão.

GOMES FILHO, Antonio Magalhães. Limites ao compartilhamento de provas no processo penal. Revista Brasileira de Ciências Criminais, São Paulo, ano 24, v. 122, 2016. p. 44. O autor faz menção ainda ao termo "circolazione probatoria”, que encontra em: ROMBI, Natalia. La circolazione dele prove penali. Padova: Cedam, 2003; FERRUA, Paolo. La prova nel processo penale. v. I. Torino: Giappichelli, 2015. p. 179 ss.

87 Um processo penal sem dilações indevidas é também parte dos direitos do investigado. Sobre o necessário equilíbrio entre um processo demasiadamente rápido, que suplanta garantias, e aquele que se arrasta por anos, impondo prejuízos econômicos, sociais e psicológicos ao investigado, recomenda-se: LOPES JR., Aury; BADARÓ, Gustavo Henrique Righi Ivahy. Direito ao processo penal no prazo razoável. 2. ed. Rio de Janeiro: Lumen Juris, 2009.

88 Perceba-se, no entanto, que uma coisa é utilizar uma prova de outra investigação para acusar alguém, outra, bem diferente, é utilizá-la para defender um direito fundamental que lhe pertence, utilizá-la, portanto, no âmbito de 
Ainda que estejamos diante de uma responsabilização de natureza não penal, é forçoso concluirmos que suas consequências, como já o dissemos (logo no início do capítulo 3), podem ser tão ou até mais pesarosas do que aquelas de natureza penal. As circunstâncias são ainda piores quando os elementos recolhidos nesse processo interno de investigação, que culminou na responsabilização não penal do investigado, são compartilhados para levar a uma condenação em um processo penal. Em ambos os casos, pelas implicações que podem existir em direitos e garantias fundamentais, convém que se observem determinados limites. ${ }^{89}$ É, portanto, imperioso que se estabeleça uma margem mais apertada de discricionariedade.

Na esfera processual penal, consolidou-se a ideia de que uma prova digna de um ambiente que se pretende democrático é aquela recolhida a partir de procedimentos que direcionam sua atenção, tanto quanto possível, ao respeito à intimidade da vida privada, ao nemo tenetur se ipsum acusare, à presunção de inocência, ao contraditório, à ampla defesa, enfim, a uma série de limites que, antes de se colocarem como obstáculos intransponíveis, são mecanismos de prevenção contra o arbítrio e contra os excessos que eventualmente se pretenda praticar no exercício do poder punitivo. Mas, mesmo nessa ótica, o compartilhamento da prova produzida apresenta algumas importantes objeções.

Para que se tenha uma ligeira ideia sobre algumas das implicações desse compartilhamento na esfera do contraditório, embora entre processos de mesma natureza, lembra-nos Antonio Magalhães Gomes Filho ${ }^{90}$,

um direito de defesa. Não menosprezamos essa diferença, razão pela qual nosso foco consiste na possibilidade de utilização desse tipo de prova em prejuízo do investigado.

89 Sobre algumas das limitações de órgãos não essencialmente policiais, mesmo que se referindo especificamente às comissões parlamentares de inquérito, vale a leitura de: BADARÓ, Gustavo Henrique Righi Ivahy. Limites aos poderes investigatórios das comissões parlamentares de inquérito. Boletim do Instituto Brasilero de Ciências Criminais, n. 83, out., 1999.

90 GOMES FILHO, Antonio Magalhães. Limites ao compartilhamento de provas no processo penal. Revista Brasileira de Ciências Criminais, São Paulo, ano 24, v. 122, 2016. p. 53. Sobre os demais aspectos da prova, do mesmo autor, recomenda-se: GOMES FILHO, Antonio Magalhães. Direito à prova no processo penal. São Paulo: RT, 1997. 
ao convocar a advertência de Paolo Ferrua ${ }^{11}$, que "somente com alguma compressão o contraditório para a prova realizado em um processo pode valer em relação a imputação diversa; a rigor, mesmo quando o acusado seja o mesmo, a estratégia defensiva muda segundo o crime que lhe é atribuído e somente com algum esforço o contraditório para a prova realizado em um processo pode valer em relação a imputação diversa”.

Antonio Magalhães Gomes Filho ${ }^{92}$ traz-nos ainda os argumentos de Aury Lopes Jr. ${ }^{93}$, para quem "a prova produzida em um processo está vinculada a um determinado fato e réu (ou réus); ao ser trasladada automaticamente, está-se esquecendo a especificidade do contexto fático que a prova pretende reconstruir; o diálogo que se estabelece com a prova é vinculado ao fato que se quer apurar ou negar; logo, diferentes diálogos são estabelecidos com a mesma prova quando se trata de apurar diferentes fatos”. E conclui: "a prova emprestada desconsidera isso e causa sérios prejuízos para todos no processo penal”. Diante disso, a admissibilidade desse compartilhamento somente se sustentaria num "exame caso a caso". ${ }^{4}$

Não obstante as objeções que, com razão, têm sido feitas - para que avancemos até um cenário que provavelmente não se consiga evitar, pois, como dissemos (no capítulo 3), há uma tendência de privatização em curso sobre determinadas atividades estatais -, partamos do pressuposto de que esse compartilhamento considera as limitações já impostas no âmbito do processo penal. ${ }^{55}$ Dito mais específica e resumidamente,

91 FERRUA, Paolo. La prova nel processo penale. v. 1. Torino: Giappichelli, 2015. p. 180. Parte importante do presente trabalho do autor pode ser encontrado no Brasil em: FERRUA, Paolo. La prova nel processo penale. Revista Brasileira de Direito Processual Penal, Porto Alegre, vol. 4, n. 1, p. 81-128, jan.-abr. 2018. GOMES FILHO, Antonio Magalhães. Limites ao compartilhamento de provas no processo penal. Revista Brasileira de Ciências Criminais, São Paulo, ano 24, v. 122, 2016. p. 53. LOPES JR., Aury. Direito processual penal. 9. ed. São Paulo: Saraiva, 2012. p. 584.

94 Essa é a conclusão apresentada pelo professor da Universidade de São Paulo. GOMES FILHO, Antonio Magalhães. Limites ao compartilhamento de provas no processo penal. Revista Brasileira de Ciências Criminais, São Paulo, ano 24, v. 122, 2016. p. 53.

95 Para uma análise mais aprofundada a respeito dessas limitações no compartilhamento, recomenda-se: TALAMINI, Eduardo. Prova emprestada no processo civil e penal. Revista de Informação Legislativa, Brasília a. 35 n. 140 out./ dez. 1998. 
para parte da doutrina, quatro devem ser os requisitos a essa admissibilidade: a) serem os fatos apurados semelhantes; b) ter sido produzida em processo entre as mesmas partes ou no qual figure como parte quem lhe suportará os efeitos; c) a observância do procedimento sobre a natureza originária da prova; e d) a observância do procedimento sobre a prova documental. ${ }^{96}$

Em sendo assim, para Eduardo Talamini ${ }^{97}$, uma vez "preenchidos os pressupostos específicos e genéricos, a parte tem direito a que se proceda ao empréstimo”. Segundo o autor, "nessa hipótese, a simples possibilidade de sua reprodução não é motivo para a inadmissão", o que "não significa, contudo, que a prova emprestada receberá sempre, absoluta e necessariamente, o valor que talvez possuísse em sua essência originária”. E mais: uma vez trasladada, “o juiz, no caso concreto e motivadamente, conferir-lhe-á o valor que ela mereça”. E conclui: “ausentes os requisitos constitucionais para sua admissão, não é concebível nem mesmo sua permanência nos autos do segundo processo".

Perceba-se, no entanto, que as análises com as quais nos deparamos estão quase sempre vinculadas ao compartilhamento de provas entre processos de mesma natureza. A doutrina, de um modo geral, é relativamente produtiva quanto aos requisitos necessários ao compartilhamento de provas entre juízos penais ou entre juízos cíveis e penais, mas pouco numerosa quando o assunto envolve o que se produz como prova no âmbito dos programas de compliance. Ademais, não nos é dado olvidar que nessas investigações internas normalmente somos apresentados a um quadro em que "a pessoa individual se depara com dois gigantes: 0 Estado e a empresa, que, é também uma grande multinacional, pode ter um poder maior que muitos Estados". ${ }^{98}$

96 Conforme apanhado em: ARANHA, Adalberto José Q. T. de Camargo. Da prova no processo penal. $7^{\mathrm{a}}$ ed. rev. e atual. São Paulo: Saraiva, 2006. p. 256; DEMCZUK, Claudio. O uso da prova emprestada no processo penal. Revista de Informação Legislativa, Brasília ano 49, n. 193, jan.-mar., 2012. p. 289; INELLAS, Gabriel César Zaccaria de. Da prova em matéria criminal. São Paulo: J. de Oliveira, 2000. p. 118.

97 TALAMINI, Eduardo. Prova emprestada no processo civil e penal. Revista de Informação Legislativa, Brasília a. 35 n. 140 out./dez. 1998. p. 159.

98 MARTÍN, Adán Nieto. Problemas fundamentales del cumplimiento normativo en el derecho penal. KUHLEN, Lothar; MONTIEL, Juan Pablo; URBINA 
Ainda que não advoguemos qualquer espécie de paralisação do sistema estatal de controle e de fiscalização ante essa nova realidade, ou seja, com empresas que têm se estruturado com aparatos investigativos altamente sofisticados e eficientes - impulsionadas pelo advento das tecnologias -, é necessário apontarmos para a busca de um "equilíbrio de poderes aceitáveis". Como adverte Adán Nieto Martín"9, "a alta direção de uma empresa é a que tem o poder interno dentro da entidade, poder que a permite ocultar seus delitos ou fabricar bodes expiatórios". Portanto, para o mencionado autor, "se a investigação interna é a antessala do processo penal, deve oferecer garantias similares”.

Nesse particular, merecem ainda relevo as questões vinculadas ao regime geral das proibições de provas, com o qual, aliás, as empresas precisam se familiarizar. A propósito disso, Karl-Heinz Gössel ${ }^{100}$ aduz que "de há muito que se vem tentando desenvolver a doutrina das proibições de prova segundo duas vias divergentes: de um lado, a partir da essência da prova e das proibições de prova; de outro lado, privilegiando-se, inversamente, as consequências de desrespeito das proibições de prova”. Jorge de Figueiredo Dias ${ }^{101}$ sustenta que "deve abrir-se mão de uma aproximação monista da teoria processual penal das proibições de prova, em favor de uma consideração diferenciada, que tome em conta no caso concreto os valores conflituantes e, sempre que possível, a sua otimização”.

GIMENO, Íñigo Ortiz de. Compliance y teoría del derecho penal. Madrid: Marcial Pons, 2013. p. 48. Tradução livre.

99 A expressão anteriormente aspeada também pertence ao autor: MARTíN, Adán Nieto. Problemas fundamentales del cumplimiento normativo en el derecho penal. KUHLEN, Lothar; MONTIEL, Juan Pablo; URBINA GIMENO, Íñigo Ortiz de. Compliance y teoría del derecho penal. Madrid: Marcial Pons, 2013. p. 48. Tradução livre.

${ }^{100}$ GÖSSEL, Karl-Heinz. As proibições de prova no direito processual penal da República Federal da Alemanha. Trad. Manuel da Costa Andrade. Revista Portuguesa de Ciência Criminal, Lisboa, ano 2, v. 3, jul.-set., 1992. p. 398.

${ }^{101}$ FIGUEIREDO DIAS, Jorge de. Revisitação de algumas ideias-mestras da teoria das proibições da prova em processo penal (também à luz da jurisprudência constitucional portuguesa). Revista de Legislação e de Jurisprudência, ano 146, n. 4000, set.-out., 2016. p. 14. 
Para o catedrático de Coimbra ${ }^{102}$ " "toda regra processual probatória contém, na medida em que ordena um determinado procedimento, a proibição de proceder de outro modo". Segundo ele, "se uma tal proibição é violada, tal não conformaria porém motivo inevitável para recusar como proibida a prova obtida”. Ainda segundo ele, "justamente por isso, a proibição violada não constitui razão de recurso da decisão que a propósito viesse a ter lugar no processo penal onde se discutisse a validade da prova alcançada". O que não aconteceria diante de uma autêntica proibição de prova, pois "tais proibições constam de normas jurídicas cuja violação afeta a prova como tal, por mais que esta possa revelar-se adequada à investigação da verdade e corresponda, em pura realidade histórica, efetivamente a esta".

Diante das preocupações sucintamente apresentadas, importa-nos, com a presente pesquisa acadêmica, procurar estimular que se reflita criticamente, cada vez mais, sobre "cómo el compliance puede integrarse en el sistema penal". ${ }^{103}$ É uma aproximação que nos tem sido apresentada como inevitável. Resta-nos descobrir, no entanto, se, de fato, haverá algum equilíbrio nesse processo de cooperação entre ramos de natureza tão diversa. O que não se espera, ao menos de nossa parte, é uma tentativa de colonização de um ramo sobre o outro. Em tal caso, convém nos questionarmos se seria o compliance a assumir características penais ou o direito penal a assumir características comuns aos tais programas de compliance.

\section{Considerações finaIS}

Tentamos, tanto quanto nos foi possível, evitar o enfrentamento direto das tormentosas questões vinculadas ao tema da prova no âmbito de um processo judicializado. Discussões sobre a alegada

\footnotetext{
102 Idem, p. 6.

${ }^{103}$ MARTÍN, Adán Nieto. Problemas fundamentales del cumplimiento normativo en el derecho penal. KUHLEN, Lothar; MONTIEL, Juan Pablo; URBINA GIMENO, Íñigo Ortiz de. Compliance y teoría del derecho penal. Madrid: Marcial Pons, 2013. p. 49.
} 
necessidade da busca pela verdade, ${ }^{104}$ por exemplo, foram deliberadamente deixadas de lado por conta da natureza ensaística da presente pesquisa. Justo por isso registramos, desde o primeiro momento, que o que mais nos interessava eram as nuances da produção da prova nos programas de compliance, fora, portanto, do ambiente judicializado. A partir daí, com a profundidade que nos foi permitida, é que nos deslocamos ao debate sobre a utilização desse tipo de prova no âmbito do processo penal.

Essa invasão da iniciativa privada nos domínios outrora considerados incontestes dos agentes estatais, impactando decisivamente no processo penal, precisa ser melhor confrontada com os valores democráticos. Daí porque o contraditório, a ampla defesa, a presunção de inocência, o nemo tenetur se ipsum acusare, o acesso a instâncias recursais, entre tantos outros, não podem ser critérios negligenciados nas investigações internas deflagradas pelas pessoas coletivas. No atual estado da arte, a dinâmica do compartilhamento de provas do ambiente essencialmente privado para o público deve reconhecer limites mais rígidos para que a consideremos validamente.

Por fim, embora não possamos apontar com absoluta segurança os rumos que, muito em breve, deverão tomar os programas de compliance diante dessa inevitável aproximação junto ao processo penal que se pretende democrático, é possível afirmarmos, na esteira do célebre poema de José Régio, por onde não nos é permitido caminhar. Sejam quais forem os caminhos pretendidos pelas empresas e pelos legisladores, as garantias historicamente conquistadas para o processo penal não podem ser simplesmente esquecidas no âmbito dos programas de compliance. Se assim não for, a certeza que temos, tal como aquela expressa pelo poeta português em seu Cântico Negro, é a de que "sei que não vou por aí".

${ }^{104}$ Nesse aspecto, em termos processuais penais e civis, respectivamente, recomenda-se: KHALED JÚNIOR, Salah Hassan. A busca da verdade no processo penal: para além da ambição inquisitorial. São Paulo: Atlas, 2013; OLIVER MAESTRE, Sara J. Prueba, proceso civil y verdad, derecho positivo, filosofía y lógica. Diario de La Ley, n. 7.128, ano XXX, mar., 2009; Vale também a leitura de: TARUFFO, Michele. Ermeneutica, prova e decisione. Revista Brasileira de Direito Processual Penal, Porto Alegre, vol. 4, n. 1, p. 129-148, jan.-abr. 2018. 


\section{REFERÊNCIAS}

AMADO, João Leal. Contrato de trabalho: noções básicas. Coimbra: Almedina, 2016.

ANTUNES, Maria João. Privatização das investigações e compliance criminal. Revista Portuguesa de Ciência Criminal, Coimbra, ano 28, n. 1, jan-abr, 2018. p. 120.

ANTUNES, Maria João. Direito processual penal. Coimbra: Almedina, 2016.

ANTUNES, Maria João. A responsabilidade criminal das pessoas colectivas entre o direito penal tradicional e o novo direito penal. Lusíada: Revista de direito e cultura, Porto, n. 1-2, 2003.

ARANHA, Adalberto José Q. T. de Camargo. Da prova no processo penal. 7. ed. rev. e atual. São Paulo: Saraiva, 2006.

BACIGALUPO, Enrique. Compliance y Derecho penal. Navarra: Aranzadi, 2011.

BADARÓ, Gustavo Henrique Righi Ivahy. Processo penal. 4. ed. São Paulo: RT, 2016.

BADARÓ, Gustavo Henrique Righi Ivahy. Limites aos poderes investigatórios das comissões parlamentares de inquérito. Boletim do Instituto Brasileiro de Ciências Criminais, n. 83, out., 1999.

BENEDETTI, Carla Rahal. Criminal Compliance: Instrumento de Prevenção Criminal Corporativa e Transferência de Responsabilidade Penal. Revista de Direito Bancário e do Mercado de Capitais, São Paulo, v. 59, jan. 2013.

BEVIÁ, Jordi Gimeno. Compliance y proceso penal. El proceso penal de las personas jurídicas - adaptada a las reformas del CP LECRIM, circular FGE 1/2016 y jurisprudencia del TS. Navarra: Aranzadi, 2016.

BOCK, Dennis. Compliance y deberes de vigilancia en la empresa. KUHLEN, Lothar; MONTIEL, Juan Pablo; URBINA GIMENO, Íñigo Ortiz de. Compliance y teoría del derecho penal. Madrid: Marcial Pons, 2013.

BRAITHWAITE, John. The new regulatory state and the transformation of criminology. British Journal of Criminology, n. 40, pp. 222-238, 2000.

BRITO, Teresa Quintela de. Relevância dos mecanismos de 'compliance' na responsabilização penal das pessoas colectivas e dos seus dirigentes. Anatomia do crime - Revista de Ciências Jurídico-Criminais, Coimbra, n. 0, jul.-dez., pp. 75-91, 2014.

CARDONA RUBERT, María Belén. El derecho a la intimidad en la relación laboral. Ius et Praxis, Chile, año 4, (2), 1998. 
CASTANHEIRA NEVES, António. Lições de introdução ao estudo do direito. Coimbra: Coimbra, 1968-69.

CORDEIRO, António Meneses. Da boa-fé no direito civil. Coimbra: Almedina, 2015. CORDEIRO, António Meneses. Manual de Direito do trabalho. Coimbra: Almedina, 1991.

COSTA ANDRADE, Manuel da. Nemo tenetur se ipsum acusare e o direito tributário. Ou a insustentável indolência de um acórdão ( $\left.n^{\circ} 340 / 2013\right)$ do Tribunal Constitucional. Revista de Legislação e de Jurisprudência, ano $144^{\circ}, \mathrm{n}^{\circ} 3.989$, novembro-dezembro, 2014.

COSTA ANDRADE, Manuel da. Sobre as proibições de provas em processo penal. Coimbra: Coimbra, 2013.

CRAWFORD, Adam; HUCKLESBY, Anthea (ed.). Legitimacy and compliance in criminal justice. New York: Routledge, 2013.

DAMIÃO DA CUNHA, José Manuel. O conceito de funcionário, para efeito de lei penal e a "privatização" da administração Pública. Uma revisão do comentário ao art. $386 .^{\circ}$ do Código Penal - Comentário Conimbricense do Código Penal. Coimbra: Coimbra, 2008.

DEMCZUK, Claudio. O uso da prova emprestada no processo penal. Revista de Informação Legislativa, Brasília ano 49, n. 193, jan.-mar., 2012.

ESTRADA I CUADRAS, Albert; ANGLÍ, Mariona Llobet. Derechos de los trabajadores y deberes empresario. SILVA SÁNCHEZ, Jesús-María (Dir.) Criminalidad de empresa y compliance - Prevención y reacciones corporativas. Barcelona: Atelier, 2013.

FARIA COSTA, José de; COSTA ANDRADE, Manuel da. Sobre a concepção e os princípios do direito penal económico. In: IDPEE - Direito penal económico e europeu: textos doutrinários. V. I. Coimbra: Coimbra, 1998.

FARIA COSTA, José de. Noções fundamentais de Direito Penal - fragmenta iuris poenalis. 4. ed. Coimbra: Coimbra, 2015.

FARIA COSTA, José de. A responsabilidade jurídico-penal da empresa e dos seus órgãos (ou uma reflexão sobre a alteridade nas pessoas colectivas à luz do direito penal). Revista Portuguesa de Ciência Criminal, Lisboa, ano 2, n. 4, out.-dez., 1992.

FERRUA, Paolo. La prova nel processo penale. Revista Brasileira de Direito Processual Penal, Porto Alegre, vol. 4, n. 1, p. 81-128, jan.-abr. 2018. http://dx.doi. org/10.22197/rbdpp.v4i1 
FERRUA, Paolo. La prova nel processo penale. v. I. Torino: Giappichelli, 2015.

FIGUEIREDO DIAS, Jorge; COSTA ANDRADE, Manuel da; COSTA PINTO, Frederico de Lacerda da. Supervisão, direito ao silêncio e legalidade da prova. Coimbra: Almedina, 2009.

FIGUEIREDO DIAS, Jorge de. Revisitação de algumas ideias-mestras da teoria das proibições da prova em processo penal (também à luz da jurisprudência constitucional portuguesa). Revista de Legislação e de Jurisprudência, ano 146, n. 4000, set.-out., 2016.

FIGUEIREDO DIAS, Jorge de. Para uma dogmática do direito penal secundário. In: IDPEE - Direito penal económico e europeu: textos doutrinários. V. I. Coimbra: Coimbra, 1998.

FIGUEIREDO DIAS, Jorge de. Direito Processual Penal. Coimbra: Coimbra, 1974. GOMES CANOTILHO, J. J.; MOREIRA, Vital. Constituição da República Portuguesa Anotada - v. I. 4. ed. Coimbra: Coimbra Editora, 2014.

GOMES FILHO, Antonio Magalhães. Limites ao compartilhamento de provas no processo penal. Revista Brasileira de Ciências Criminais, São Paulo, ano 24, v. $122,2016$.

GOMES FILHO, Antonio Magalhães. Direito à prova no processo penal. São Paulo: RT, 1997.

GOÑI SEIN, José Luis, Programas de cumplimiento empresarial (compliance programs): aspectos laborales. MIR PUIG, Santiago; CORCOY BIDASOLO, Mirentxu; GÓMEZ MARTÍN, Víctor (Dirs.); HORTAL IBARRA, Juan Carlos; VALIENTE IBÁÑEZ, Vicente (Coords.). Responsabilidad de la empresa y compliance. Programas de prevención, detección y reacción penal. Montevideo-Buenos Aires: B de F, 2014.

GÖSSEL, Karl-Heinz. As proibições de prova no direito processual penal da República Federal da Alemanha. Trad. Manuel da Costa Andrade. Revista Portuguesa de Ciência Criminal, Lisboa, ano 2, v. 3, jul.-set., 1992.

INELLAS, Gabriel César Zaccaria de. Da prova em matéria criminal. São Paulo: J. de Oliveira, 2000.

KHALED JÚNIOR, Salah Hassan. A busca da verdade no processo penal: para além da ambição inquisitorial. São Paulo: Atlas, 2013.

KUHN, Thomas S. A estrutura das revoluções científicas. Trad. Beatriz Vianna Boeira e Nelson Boeira. 12. ed. São Paulo: Perspectiva, 2013. 
LAINGUI, André. Sur quelques sujets non-humains des anciens droits pénaux. ROBERT, Jacques-Henri; TZITIS, Stamatios. La personne juridique dans la philosophie du droit penal. Paris: Éditions Panthéon Assar, 2001.

LASCURAÍN, Juan Antonio. Los programas de cumplimiento como programas de prudencia penal. Revista Portuguesa de Ciência Criminal, Coimbra, ano 25, n. 1 a 4 , jan.-dez., 2015.

LAUFER, William S. Corporate Bodies and Guilty Minds - the failure of corporate criminal liability. Chicago: University of Chicago Press, 2006.

LOBATO, José Danilo Tavares; MARTINS, Jorge Washington Gonçalves. Considerações preliminares acerca da responsabilidade criminal do compliance officer. Boletim do Instituto Brasileiro de Ciências Criminais, São Paulo, v. 24, n. 284, jul., 2016.

LOPES JR., Aury. Fundamentos do processo penal - introdução crítica. Lisboa: Rei dos Livros, 2016.

LOPES JR., Aury. Direito processual penal. 9. ed. São Paulo: Saraiva, 2012.

LOPES JR., Aury; BADARÓ, Gustavo Henrique Righi Ivahy. Direito ao processo penal no prazo razoável. 2. ed. Rio de Janeiro: Lumen Juris, 2009.

LUHMANN, Niklas. El derecho de la sociedad. México: Universidad Iberoamericana, 2002.

LUHMANN, Niklas. Sociologia do Direito. v. I e II. Rio de Janeiro: Edições Tempo Brasileiro, 1983.

MANACORDA, Stefano; CENTONZE, Francesco; FORTI, Gabrio. (ed.) Preventing Corporate Corruption - the anti-bribery compliance model. New York: Springer, 2014.

MARTÍN, Adán Nieto. Compliance programs en materia de derechos humanos. Colóquio “Direito penal económico em mudança”. Auditório da Faculdade de Direito da Universidade de Coimbra, 20 mar. 2018.

MARTÍN, Adán Nieto. Problemas fundamentales del cumplimiento normativo en el derecho penal. KUHLEN, Lothar; MONTIEL, Juan Pablo; URBINA GIMENO, Íñigo Ortiz de. Compliance y teoría del derecho penal. Madrid: Marcial Pons, 2013.

MARTÍN, Adán Nieto. La privatización de la lucha contra la corrupción. Cahiers de defense sociale - pour una politique criminelle humaniste, 2011-2012. Disponível em: http://www.defensesociale.org/CAHIERS_2012/Cahiers_2011-2012_PDF. pdf. Acesso em 27 mar. 2018. 
MARTÍN, Adán Nieto. ¿Americanización o europeización del Derecho Penal económico? Revista Penal, España, n. 19, p. 120-136, 2007.

MARTÍN, Adán Nieto. La responsabilidad penal de las personas jurídicas: un modelo legislativo. Madrid: Iustel, 2008.

MARTÍN, Adán Nieto. La corrupción en el comercio internacional (o de cómo la americanización del derecho penal puede tener de vez en cuando algún efecto positivo). Revista Penal, España, n. 12, p. 3-26, 2003.

MITTERMAYER, Carl Joseph Anton. Tratado da prova em matéria criminal - ou exposição comparada dos princípios da prova em matéria criminal, etc., de suas aplicações diversas na Alemanha, França, Inglaterra, etc. 3. ed. Trad. Alberto Antonio Soares. Rio de Janeiro: Jacinto Ribeiro dos Santos, 1917.

MOOSMAYER, Klaus. Anforderungen an den Compliance-Beauftragten. ROTSCH, Thomas (org.). Criminal Compliance. Baden-Baden: Nomos, 2015.

MÜLLER, Julio Guilherme. Negócios processuais e desjudicialização da produção da prova - análise econômica e jurídica. São Paulo: Revista dos Tribunais, 2017.

NEIRA, Ana María. La efectividad de los criminal compliance programs como objeto de prueba en el proceso penal. Política criminal. v. 11, n. 22, Diciembre, 2016.

OLIVER MAESTRE, Sara J. Prueba, proceso civil y verdad, derecho positivo, filosofía y lógica. Diario de La Ley, n. 7128, ano XXX, mar., 2009.

PAIS, Ana. Os programas de compliance e o risco de privatização do processo penal. Em especial, a problemática da 'prova emprestada' e o princípio do nemo tenetur se ipsum accusare. Boletim da Faculdade de Direito da Universidade de Coimbra - Estudos em homenagem ao Prof. Doutor Manuel da Costa Andrade, v. II, 2017.

PINTO MONTEIRO. António. Cláusulas limitativas e de exclusão de responsabilidade civil. Dissertação para exame de pós-graduação em Ciências Jurídico-Civis na Faculdade de Direito da Universidade de Coimbra. Coimbra: Coimbra, 1985.

PLANAS, Ricardo Robles. El responsable de cumplimiento («Compliance Officer») ante el Derecho penal. SILVA SÁNCHEZ, Jesús-María (Dir.) Criminalidad de empresa y compliance - Prevención y reacciones corporativas. Barcelona: Atelier, 2013.

PORCIÚNCULA, José Carlos. Delator não pode incitar interlocutor a cometer crimes para denunciá-los depois. Revista Consultor Jurídico, Brasília, jul., 2017. Disponível em: https://www.conjur.com.br/2017-jul-04/jose-porciuncula-ilegalidades-gravacao-joesley-batista. Acesso em 30 abr. 2018 
RAGUÉS I VALLÈS, Ramon. Whistleblowing: una aproximación desde el derecho penal. Madrid: Marcial Pons, 2013.

RAGUÉS I VALLÈS. Los procedimientos internos de denuncia como medida de prevención de delitos en la empresa. SILVA SÁNCHEZ, Jesús-María (Dir.) Criminalidad de empresa y compliance -Prevención y reacciones corporativas. Barcelona: Atelier, 2013.

RIOS, Rodrigo Sánchez; MACHADO, Allian Djeyce Rodrigues. Criminalidade intraempresarial, sistemas de denunciação interna e suas repercussões na seara penal: o fenômeno do whistleblowing. Revista do Instituto Brasileiro de Ciências Criminais, São Paulo, ano 25, n. 137, 2017.

RODRIGUES, Anabela Miranda. Compliance programs and corporate criminal compliance. PoLaR - Portuguese Law Review, v. 2, n. 1, jan., 2018. p. 1. Disponível em: http://www.portugueselawreview.pt/wp-content/uploads/2018/05/ PoLaR-Vol.-2-No.-1-January-2018-1.pdf. Acesso em 1 jun. 2018.

RODRIGUES, Anabela Miranda. Direito penal económico - é legítimo? É necessário? Revista Brasileira de Ciências Criminais, São Paulo, ano 25, n. 127, 2017.

ROMBI, Natalia. La circolazione dele prove penali. Padova: Cedam, 2003.

SAVATIER, René. L'iflation législative et l'indigestion du corps social. Paris: Dalloz, 1977.

SAVATIER, René. Les Métamorphoses économiques et sociales du Droit Civil d'Aujourd'hui. 3. ed. Paris: Dalloz, 1964.

TALAMINI, Eduardo. Prova emprestada no processo civil e penal. Revista de Informação Legislativa, Brasília a. 35 n. 140 out./dez. 1998.

TOMILLO, Manuel Gómez. Compliance penal y política legislativa - el deber personal y empresarial de evitar la comisión en el seno de las personas jurídicas. Valencia: Tirant lo blanch, 2016.

SARLET, Ingo Wolfgang. Dignidade da pessoa humana e direitos fundamentais na Constiuição Federal de 1988. 2. ed. Porto Alegre: Livraria do Advogado, 2002.

SIEBER, Ulrich. Programas de 'compliance' en el derecho penal de la empresa. Una nueva concepción para controlar la criminalidad económica. Trad. Abanto Vásquez. El Derecho Penal Económico en la era Compliance. ARROYO ZAPATERO, Luis; NIETO MARTÍN, Adán (Dir.). Valencia: Tirant lo blach, 2013. 
TARUFFO, Michele. Ermeneutica, prova e decisione. Revista Brasileira de Direito Processual Penal, Porto Alegre, vol. 4, n. 1, p. 129-148, jan.-abr. 2018. http:// dx.doi.org/10.22197/rbdpp.v4i1.136

WACQUANT, Loïc. As prisões da miséria. Trad. André Telles. Rio de Janeiro: Zahar, 2011.

WACQUANT, Loïc. Punir os pobres - a nova gestão da miséria nos Estados Unidos. Trad. Sérgio Lamarão. Rio de Janeiro: Revan, 2003.

\section{Informações adicionais e declarações dos autores (integridade científica)}

Agradecimentos (acknowledgement): Meus agradecimentos ao Centro Universitário Cesmac (Maceió/AL), que me permitiu o licenciamento da condição de professor em seus quadros para a realização da pesquisa in loco na Universidade de Coimbra (PT).

Declaração de conflito de interesses (conflict of interest declaration): o autor confirma que não há conflitos de interesse na realização das pesquisas expostas e na redação deste artigo.

Declaração de autoria e especificação das contribuições (declaration of authorship): todas e somente as pessoas que atendem os requisitos de autoria deste artigo estão listadas como autores; todos os coautores se responsabilizam integralmente por este trabalho em sua totalidade.

Declaração de ineditismo e originalidade (declaration of originality): o autor assegura que o texto aqui publicado não foi divulgado anteriormente em outro meio e que futura republicação somente se realizará com a indicação expressa da referência desta publicação original; também atesta que não há plágio de terceiros ou autoplágio. 
Dados do processo editorial

(http://www.ibraspp.com.br/revista/index.php/RBDPP/about/editorialPolicies)

- Recebido em: 13/06/2018

Equipe editorial envolvida

- Controle preliminar e verificação de plágio: 17/06/2018

- Avaliação 1: 21/06/2018

- Avaliação 2: 26/06/2018

- Avaliação 3: 03/07/2018

- Decisão editorial preliminar: 21/07/2018

- Retorno rodada de correções 1: 03/08/2018

- Decisão editorial preliminar 2: 04/08/2018

- Retorno rodada de correções 2: 07/08/2018

- Decisão editorial final: 15/08/2018

\section{COMO CITAR ESTE ARTIGO:}

FRANÇA JÚNIOR, Francisco de Assis de. Pessoas Coletivas e os Programas de Compliance: A Problemática da Prova Compartilhada com o Processo Penal de Pretensão Democrática. Revista Brasileira de Direito Processual Penal, Porto Alegre, vol. 4, n. 3, p. 1277-1318, set./dez. 2018. https://doi.org/10.22197/rbdpp.v4i3.170

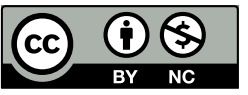

Esta obra está licenciada com uma Licença Creative Commons Atribuição-NãoComercial 4.0 Internacional. 